University of Massachusetts Amherst

ScholarWorks@UMass Amherst

Published Work

Center for Student Success Research

2016

\title{
Socioeconomic Disparities in the Use of College Admission-Enhancing Strategies among High School Seniors from the 1990s to 2000 s
}

\author{
Ryan Wells \\ University of Massachusetts Amherst \\ Gregory Wolniak \\ New York University \\ Marc Engberg \\ Loyola University Chicago \\ Catherine A. Manly \\ University of Massachusetts Amherst
}

Follow this and additional works at: https://scholarworks.umass.edu/cfssr_publishedwork

Part of the Higher Education Commons, and the Social and Philosophical Foundations of Education Commons

\section{Recommended Citation}

Wells, Ryan; Wolniak, Gregory; Engberg, Marc; and Manly, Catherine A., "Socioeconomic Disparities in the Use of College Admission-Enhancing Strategies among High School Seniors from the 1990s to 2000s" (2016). Teachers College Record. 2.

Retrieved from https://scholarworks.umass.edu/cfssr_publishedwork/2 


\title{
Socioeconomic Disparities in the Use of College Admission-Enhancing Strategies among High School Seniors from the 1990 s to 2000 s
}

\author{
RYAN WELLS \\ University of Massachusetts, Amherst \\ GREGORY WOLNIAK \\ New York University \\ MARC ENGBERG \\ Loyola University Chicago
}

CATHERINE A. MANLY

University of Massachusetts, Amherst

Background/Context: Researchers have examined a number of admission-enhancing strategies utilized by students to strengthen their college applications. These academic and nonacademic strategies represent a range of opportunities differentially accessed by students, which can bolster their college profiles and increase their overall likelihood of college enrollment.

Purpose/Objective: The purpose of this study is to determine if the relationship between students' socioeconomic status (SES) and use of admission-enhancing strategies changed over time. We address the following specific research questions:

- To what extent were there differences in the use of admission-enhancing strategies between low- and high-SES students in the 1990s and 2000s?

- To what extent did these relationships between SES and the use of admission-enhancing strategies differ by academic achievement?

- To what extent did SES gaps increase, decrease, or remain stable between the 1990 s and the 2000s? 
Research Design: This study utilized a correlational design, via secondary data analysis. Specifically, the analytic plan for this study consisted of three main parts: 1) descriptive statistics, including analyses of mean differences and change over time, 2) logistic regression to determine how SES predicts the use of college admission-enhancing strategies separately by cohort, and 3) comparison of predicted probabilities of strategy use by SES within cohorts, as well as over time between cohorts.

Findings/Results: SES is related to greater use of these strategies among high school students, and this relationship has been maintained over time. Additionally, specifically comparing changes in the gap of strategy use between high-and low-SES students reveals that inequality has not only been maintained, but has increased over time.

Conclusions/Recommendations: Findings contribute to a growing body of literature examining educational inequalities. Results also imply that admissions processes and decisions should be conducted with awareness of the stratifying nature of these admission-enhancing strategies. The findings also lead to the suggestion that more programs are needed that foster greater involvement among low-SES students in activities that will be seen as desirable by selective institutions and aid them in going to a college of their choice.

In recent decades, the most selective American colleges and universities have become even more competitive, a trend that is partially explained through increases in the number of admissible students, higher rates of enrollment, and escalating costs of attendance (Alon \& Tienda, 2007; Bastedo \& Jaquette, 2011; Hoxby, 2009). Despite staggering increases in average tuition and fees (College Board, 2012), four-year enrollment rates among 18-24 year olds have increased from $23.3 \%$ to $28.2 \%$ from 1990 through 2010 (National Center for Educational Statistics [NCES], 2012a), translating to approximately four million additional students in the system (NCES, 2012). However, when examining trends by students' socioeconomic backgrounds over the same time period, the college enrollment gap between high- and low-income high school completers has remained essentially unchanged with an approximately 30-point difference in enrollment rates (NCES, 2012). This exists within a broader context where over many decades gaps in enrollment and completion between students from the lowest and highest income quartiles have increased (Bailey \& Dynarski, 2011). Thus, persistent patterns of stratification continue to characterize the U.S. postsecondary system.

In addition to consistent gaps in postsecondary enrollment rates, it is also well documented that high-SES students are increasingly concentrated in more selective institutions (e.g., Bastedo \& Jaquette, 2011; Engberg, 2012; Grodsky \& Jackson, 2009; Karen, 2002; Paulsen \& St. John, 2002). Entrance to the most selective postsecondary institutions is associated with a range of concomitant benefits, including access to better paying jobs, leadership positions in elite organizations, and 
considerably higher lifetime earnings (Dye, 2002), and may also confer the most advantage for the underrepresented students who are least likely to get in (Dale \& Krueger, 2014). Taken together, these trends suggest a weakening influence of postsecondary enrollment on social mobility for low-SES students (Alon \& Tienda, 2007; Bastedo \& Jaquette, 2011), warranting further examination of the mechanisms that perpetuate and reproduce educational inequality.

In attempting to understand persistent patterns of stratification in postsecondary enrollment, researchers have examined a number of "admission-enhancing strategies" (Espenshade \& Radford, 2009, p. 39) utilized by students to strengthen their college applications, including course-taking patterns, Advanced Placement (AP) classes, test-prep courses, and extracurricular involvement (e.g., Clinedinst, Hurley, \& Hawkins, 2011; College Board, 2011; Espenshade \& Radford, 2009; Hargrove, Godin, \& Dodd, 2008; Kaufman \& Gabler, 2004; Stevens, 2007; Weis, Cipollone, \& Jenkins, 2014). Access to these strategies may partially explain continued disparities in college enrollment based on their prominence in college admission decisions (Alon \& Tienda, 2007; Espenshade \& Radford, 2009).

More broadly, these trends align with Alon's (2009) suggestion that the cycle of inequality in higher education unfolds according to combinations of program exclusions and student adaptations. "Exclusion is primarily a collective act intended to promote class formation through careful selection of successors" (p. 735), including practices such as college admissions requirements. An adaptation is a "strategy that can preserve the kinship link and the intergenerational transmission of status" (p. 736), such as purchasing college preparatory services to enhance performance on standardized tests. We hypothesize that such student adaptations result in differential access to admission-enhancing strategies by SES, and may supplement explanations of why low-income students continue to be seen as "running in place" (Bastedo \& Jaquette, 2011), despite making significant gains in their overall academic achievement over time.

The purpose of this study is to determine if the relationship between students' SES and use of admission-enhancing strategies changed over time, during a period marked by rising demand for college, fueled by increasing numbers of college-admissible high school graduates, and escalating costs of attendance. Despite dramatic expansion, the postsecondary system has not sufficiently kept up with demand, resulting in what Alon and Tienda (2007) have labeled the "college squeeze." Under these circumstances, colleges compete with one another to identify and attract the most meritorious and diverse student body, while students increasingly rely on college selectivity rankings and the knowledge that selective schools consider a 
host of factors such as test scores, high school grades and rank, and extracurricular activities when making admissions decisions.

Prior to determining if these mechanisms have become more salient over time, we first must understand the extent to which students' SES was associated with the use of admission-enhancing strategies during high school in the 1990s, and again in the 2000s. While Espenshade and Radford's (2009) study found income disparities across different admissions-enhancing strategies, their sample was limited to a small number of postsecondary schools (eight in total) that were considered highly selective. In this study, we utilize nationally representative data samples of high school students to examine patterns of use across different admission-enhancing strategies, thereby mitigating external validity threats and allowing for important generalizations that inform policy at the national level.

We must also account for the reality that academic ability plays a key role in this process. SES and academic achievement are positively correlated, and one may presume that higher-achieving students are also more likely to utilize the strategies under investigation. Therefore, beyond examining the relationship between SES and enhancement strategies net of achievement, we also examine if the relationship varies by, or interacts with, academic achievement.

We hypothesize that the use of admission-enhancing strategies is partially an artifact of one's socioeconomic status (SES), is moderated by academic achievement, and is a mechanism that perpetuates inequality over time. To test this hypothesis, we address the following specific research questions:

- To what extent were there differences in the use of admission-enhancing strategies between low- and high-SES students in the 1990s and 2000s?

- To what extent did these relationships between SES and the use of admission-enhancing strategies differ by academic achievement?

- To what extent did SES gaps increase, decrease, or remain stable between the 1990s and the 2000s?

\section{THEORETICAL PERSPECTIVES}

The rapid expansion of the educational system in the latter half of the twentieth century was expected to ameliorate social inequalities related to educational participation and attainment; yet disparities in access have continued for disadvantaged groups, propelling a generation of new theories to explain the relationship between educational expansion and persistent patterns of inequality. This study is grounded in the notion 
that during periods of postsecondary expansion, socioeconomically advantaged groups will leverage different strategies to secure advantages in the college admissions process. Alon (2009) conceptualized this type of inequality in higher education as being partially due to program exclusions and student adaptations. She estimated postsecondary enrollment models using nationally representative data from the 1970 s, 80 s, and early 90 s, yielding support for the conclusion that adaptive behavior among higher-SES students forms the "cornerstone to building a comprehensive theory regarding the evolution of inequality." (p. 749). Her decennial cohort analysis also builds a solid foundation for our comparison of cohorts from the 1990s and the 2000s.

Another influential sociological perspective, Effectively Maintained Inequality (EMI; Lucas, 2001), contends that expansion is unlikely to attenuate inequalities in educational opportunity because families from more advantaged socioeconomic backgrounds are better positioned to capitalize on new opportunities created through expansion. EMI theory demonstrates that as postsecondary opportunities increase for all students (i.e., as inequalities in enrollment decline), access to more prestigious institutions will be restricted to those who have secured the highest socioeconomic positions (Lucas, 2001). Early research on EMI theory demonstrated the saliency of different socioeconomic indicators in predicting students' likelihood of transitioning from eleventh to twelfth grade and eventually into college (Lucas, 2001), while subsequent work determined that EMI was a scientific, falsifiable theory appropriate for continued use in studies of inequality (Lucas, 2009). Thus, EMI theory posits that students from higher socioeconomic backgrounds preserve their social standing by using their advantaged status to secure more selective educational opportunities. For this study, while not formally testing EMI theory, we conceptualize admission-enhancing strategies as those opportunities that more advantaged students will pursue (i.e., Alon's adaptations) to maximize their postsecondary enrollment options and thereby maintain inequality.

Influenced by these conceptual perspectives, we examine the role of SES in student adaptations, manifested in the form of admission-enhancing strategies in the 1990 s and 2000s. In doing so, we aim to illuminate enhancement strategies as a plausible contributing explanation for enduring socioeconomic inequality in postsecondary education.

\section{ADMISSION-ENHANCING STRATEGIES}

In an era marked by steep competition at the nation's most selective institutions, families engage in a number of strategies aimed at improving their children's academic profiles and standardized test scores (Alon \& 
Tienda, 2007). Espenshade and Radford (2009) have described these strategies as "deliberate steps to increase the chances of admission" ( $p$. 39 ), including test preparation, the use of college consultants, and AP courses (Espenshade \& Radford, 2009; Hargrove et al., 2008). Students and families also engage in strategies to improve their nonacademic profiles, including participation in extracurricular activities (Kaufman \& Gabler, 2004; Stevens, 2007) and community service (Wells \& Lynch, 2014). These academic and nonacademic strategies represent a range of opportunities differentially accessed by students, which can bolster their college profiles and increase their overall likelihood of selective college enrollment. For this study, we consider a broader definition than originally proposed by Espenshade and Radford (2009), and examine five specific strategies that students may use to increase their chances of selective college admission: 1) take or plan to take an AP exam; 2) utilize SAT preparatory instruction (a course or tutoring); 3) utilize SAT preparatory self-study materials, including books, videos, or computer programs; 4) have leadership roles in extracurricular activities; and 5) perform volunteer service.

\section{ADVANCED PLACEMENT}

AP courses are one possible means of bolstering college applications, offering students the opportunity to take college-level coursework while still in high school. It is assumed that students who take AP courses and pass the examination will experience a competitive advantage in college admissions; however, evidence concerning the impact of AP courses on college outcomes is mixed. While positive outcomes have been reported, such as better academic performance or higher graduation rates (Hargrove et al., 2008), other researchers question the causality of such relationships despite conceding that AP exams share a relationship with different academic outcomes (Klopfenstein \& Thomas, 2009).

Although AP courses were once synonymous with elite secondary education and college preparation academies, the College Board has purposefully reframed AP courses as now being available to "all willing and academically prepared students" (College Board, 2011, p. 8). For instance, from 1986 to 2010 student participation in AP grew by nearly seven times (College Board, 2010), leading some to claim that the AP has been democratized (Lacy, 2010). Despite increased access to AP, there continues to be concerns about stratification by race/ethnicity and income level for those who participate in AP courses and exams (Klopfenstein, 2004; Klugman, 2013). 
In order to improve their admissibility to selective institutions, students may try to enhance their college applications by taking part in SAT (or ACT) preparation activities in the hopes of improving their scores. Test preparation activities range from more informal or student-driven activities, including taking practice exams or buying study guides, to more formal structures, including instructor-led courses, online coaching, and private tutoring, with the formal strategies incurring appreciably higher expenses (Briggs, 2009). Despite the general belief that test preparation is a necessary step in enhancing standardized test scores, research on the effects of test preparation has been mixed. Research using data from the 1990s found small to moderate positive influences on SAT scores and subsequent selective college enrollment (Buchmann, Condron, \& Roscigno, 2010). Other research demonstrated small effects for private tutors, commercially based test courses, and test books on SAT math scores, but no effects on SAT verbal scores, and negative effects on SAT math scores for test preparation computer programs (Briggs, 2002, 2009). Despite the lack of significance for computer-based courses, these represent the largest growth in terms of use from the period of 1992 to 2004 (an increase from 21 to 25 percent) compared to a relatively stable level of use for other forms of test preparation (Briggs, 2009).

Access to test preparation remains an important issue when examining the potential benefits derived from this enhancement strategy. Buchmann et al. (2010) found that there were disparities by social class in use of SAT prep in the 1990s, particular for the more costly options of SAT courses and private tutoring. They also show differences in access by race/ethnicity (see also Byun \& Park, 2012). Similarly, research from a small group of highly selective institutions showed that students from upper-middle-class backgrounds were the most likely to take test preparation courses $(52 \%)$ compared to those in lower-class (45\%), working- and middle-class (40\%), and upper-class (49\%) socioeconomic strata (Espenshade \& Radford, 2009). These researchers noted that the real differences lie in the types of courses students had access to (i.e., private versus public), with only $8.3 \%$ of lower-class students versus $78 \%$ of upper-class students taking a private course. In the current study, we examine socioeconomic differences related to both test preparation courses and those who engage in self-study, but we extend past research by examining data from the 2000 s to determine change over time, and by examining all students in high school rather than a postenrollment elite postsecondary cohort.

Past research indicates that accessing SAT preparation opportunities depends on largely on cost. While practice materials are available for free 
from the SAT and ACT, online and commercial classes range from $\$ 400$ for an online course to $\$ 1,100$ for face-to-face instruction; each of these opportunities requires a minimal investment from 10-20 hours to over 40 hours (Briggs, 2009). Enrolling in test-prep courses also carries an opportunity cost, primarily in the form of foregone earnings, for working students, a disproportionate number of whom are from lower-SES backgrounds. Thus, higher-SES students face relatively lower opportunity costs, and are likely to receive more and/or higher quality test preparation. In addition to differences in monetary and opportunity costs, lowSES students may also underestimate the relevance of standardized tests in comparison their higher-SES peers, both in terms of admissions and in relation to their academic preparation (Deil-Amen \& Tevis, 2010).

\section{EXTRACURRICULAR ACTIVITIES}

Accompanying academic activities undertaken to improve the likelihood of college admissions are strategies involving extracurricular participation, especially leadership positions in these activities. In a recent report by the National Association for College Admission Counselors (Clinedinst et al., 2011), approximately $7.4 \%$ of admissions counselors rated extracurricular activities as being of "considerable importance," with an additional $42.3 \%$ rating these activities as being of "moderate importance." Although these trends have been stable over the last 17 years, there is variation in relation to institutional type, with private colleges showing a significant and positive correlation in relation to the importance admission counselors place on extracurricular involvement $(\mathrm{r}=.324)$. This finding supports the Espenshade and Radford (2009) study, in which increases in extracurricular involvement were associated with significantly higher probabilities of gaining admittance to an elite private college.

While the type of activity and the intensity of involvement mayvary, there exists a small body of evidence generally suggesting that extracurricular involvement is related to positive educational outcomes, including college aspirations (Hossler \& Stage, 1992), college enrollment (Marsh, 1992; Marsh \& Kleitman, 2002) and selective enrollment specifically (Kaufman and Gabler, 2004). However, the evidence is somewhat mixed, and the type of activity is likely to matter (Gibbs, Erickson, Dufur, \& Miles, 2015). Participation also has a complex relationship with student SES. First, like test preparation courses, there is an opportunity cost involved in extracurricular activities, and that cost may be substantially higher for low-income students who are employed after school and on weekends. Second, there is some conjecture that extracurricular involvement serves as a compensatory mechanism in allaying academic weaknesses for high-income 
students who are interested in attending selective postsecondary institutions (Soares, 2007). Third, while higher-SES students have more access to extracurricular activities, there is evidence that low-SES students may benefit more from involvement (Marsh, 1992; Marsh \& Kleitman, 2002). Extracurricular involvement, for instance, may be a factor in student resilience, whereby vulnerable students exceed expectations for their educational attainment (Peck, Roeser, Zarrett, \& Eccles, 2008). From an EMI perspective, it is unclear, therefore, whether access to extracurricular activities maintains advantage, or whether differential "returns" on those activities may help to lessen inequality.

\section{COMMUNITY SERVICE}

Community service (used synonymously with volunteerism for the purposes of this paper) is an additional way that students may gain advantages in the selective admissions process via activities that are outside of the academic curriculum (Espenshade \& Radford, 2009). While the Corporation for National and Community Service (CNS) reported that volunteer rates were at a 30 -year high, with over $28 \%$ of teenagers (ages.16-19) and over $30 \%$ of college students (ages 18-24) volunteering (Dote, Cramer, Dietz, \& Grimm, 2006; Grimm, Dietz, \& Foster-Bey, 2006), disparities related to this type of involvement exist at both individual and school levels (Wells \& Lynch, 2014). For instance, students from low-income families were more likely than higher-income students to attend high-poverty, underresourced schools (Orfield \& Lee, 2006) and were consistently less likely to volunteer (Marks \& Jones, 2004), especially through school-based opportunities (Kahne \& Middaugh, 2008).

Beyond the schools, family background may be a factor for volunteerism disparities. Only $27 \%$ of students from disadvantaged backgrounds had a parent serving as a volunteer role model, compared to $44 \%$ of students from nondisadvantaged backgrounds (Spring, Dietz, \& Grimm, 2007). Additionally, much the same as other enhancement strategies, there is an opportunity cost to participation that is likely to be higher for lowerSES students. Despite these challenges, there is evidence that lower-income individuals may report greater perceived benefits from volunteering (Morrow-Howell, Hong, \& Tang, 2009).

All together, the literature on admission-enhancing strategies indicates that students' use of different strategies is an important factor in maintaining patterns of stratification between students from differing socioeconomic backgrounds. EMI theory, in particular, may be useful in understanding how advantaged students' access to these strategies maintains their social standing by increasing their likelihood of obtaining admission to a highly 
selective college or university. Concomitantly, admission to a highly selective institution leads to a number of economic and social returns, including higher lifetime earnings and leadership positions in top companies (Carnevale, 2010; Dale \& Krueger, 2014; Dye, 2002). Therefore, investigating how the use of admission-enhancing strategies has changed, and how SES was related to these changes, may contribute to our understanding of why persistent patterns of stratification remain between low-and high-SES students in relation to postsecondary opportunities.

\section{METHODS}

\section{DATA AND VARIABLES}

We obtained data for this study from the National Education Longitudinal Study of 1988 (NELS) and Education Longitudinal Study of 2002 (ELS) restricted-use datasets from the National Center for Educational Statistics (NCES). Each of these surveys utilized a complex sample design to create a dataset that is nationally representative (Haggerty et al., 1996; Ingels, Pratt, Rogers, Siegel, \& Stutts, 2005). NELS began with a cohort of $8^{\text {th }}$ grade students in 1988, and followed them through four subsequent waves of data collection, the last occurring in 2000. ELS began with a cohort of $10^{\text {th }}$ graders in 2002 and followed them through three subsequent waves of data collection, with the final data collected in 2012. Importantly for this study, there were data collected from students in their senior year of high school for each dataset, both of which asked similar questions about admission-enhancing strategies and related variables. In this sense, NELS and ELS are designed as repeated cross-sections, as well as each being longitudinal in their own right. While there are some differences in administration, both datasets are designed to examine students' transitions from secondary school into postsecondary education and the workforce. For more detail about the NELS and ELS surveys, sampling, and methodological details, see Curtin, Ingels, Wu, Heuer, \& Owings (2002), Ingels et al. (1992), and Ingels et al. (2014); variables for each dataset can also be explored via NCES's online Education Data Analysis Tool (EDAT). Our analytic samples consisted of nationally representative cohorts of senior high school students from 1992 and 2004, respectively.

We included six dichotomous dependent variables derived from the NELS and ELS datasets to operationalize a range of admission-enhancing strategies: whether a student 1) took or planned to take an AP exam, 2) enrolled in SAT preparatory instruction, 3) used SAT preparatory selfstudy materials, 4) had a leadership position in extracurricular activities, or 5) participated in community service. From these five variables, we 
created a sixth, overall measure of admission-enhancing strategy usage by counting how many of the five possible strategies a student used. We then designated those who used four or five strategies as having 'high' strategy use, under the assumption that there may be an aggregate effect of strategy use as well as individual effects. This aspect of our research reflects Espenshade \& Radford's (2009) approach of examining strategies individually, but also in an aggregated manner in an attempt to examine the intensity of involvement or strategy use.

The main independent variable of interest was SES. To represent SES we used a composite variable derived from parental income, parental educational attainment, and parental occupation. We recognize that in some cases, a composite SES variable may mask relationships among individual variables that are important to a more complete understanding of the mechanisms that underlie the college choice process (e.g., Paulsen \& St. John, 2002), and that policymakers often refer to income classifications alone when designating specific policy recommendations. However, a recent report by NCES (2012b), titled Improving the Measurement of Socioeconomic Status for the National Assessment of Educational Progress, provides a thorough review of the measurement issues involved in capturing socioeconomic status and concludes that "the advantages of treating SES as a composite of several variables rather than as a single variable or multiple single variables outweigh the disadvantages" (p. 26). In particular, the report notes that examining SES through the lens of only its variable components, such as family income, is counter to conventional definitions of SES. Further, utilizing a composite index attenuates the measurement error associated with single-item metrics, eases the overall interpretation of SES, and reduces the likelihood of endogeneity effects by recognizing SES as a latent variable with formative indicators (NCES, 2012b).

The composite SES variable used in this study is valuable for several reasons. It may be considered a measure of wealth, which often is preferred over income alone' as it reflects a wider range of social and human capital considerations; it may reflect a student's overall orientation toward college better than any particular individual variable; and it may have certain statistical advantages (Adelman, 2002; Perna, 2006; Terenzini et al., 2001). This aggregation is also conceptually consistent with the three-part conceptualization of SES by Duncan et al. (1972) and more recent studies that have utilized a similar approach in examining issues of college access and stratification (Bastedo \& Jaquette, 2011; Engberg \& Wolniak, 2010; Núñez \& Bowers, 2011).

We included two variables to represent academic achievement: math standardized test score and English standardized test score. These tests 
were administered by NCES during $10^{\text {th }}$ grade, preceding the measurement of admission-enhancing strategies from when students were in the $12^{\text {th }}$ grade. These test score variables serve as vital controls in many of our models. In relation to our second research question, these are also key independent variables of interest for determining how SES and achievement in combination influence the use of enhancement strategies. We created two interaction variables with these constructs for this purposeone between math test score and SES, and one between English test score and SES. As described below, these interaction variables are used to determine how academic achievement may moderate the relationship between SES and strategy use.

At the individual level, we controlled for gender and race/ethnicity, which are also stratifying factors of college admission, as well as students' college expectations in the $10^{\text {th }}$ grade. To control for the potential influence of family and significant others, we controlled for parental college expectations and peers' college aspirations during high school. To control for salient school-level factors, we included variables for the student's high school program (general, college prep, or vocational-technical), schoolSES (proxied by the percentage of students on free or reduced lunch), urbanicity, and geographic region. ${ }^{1}$

\section{MISSING DATA ANALYSIS}

Without addressing missing data, approximately half of cases in both NELS and ELS would have been dropped via listwise deletion. Instances of missing data for individual variables were mostly below $20 \%$, but ranged as high as $34 \%$ in NELS and $32 \%$ in ELS (both for the school free lunch variable). While the total number of cases with missing data was somewhat high, the missingness was still within the threshold of reasonably being able to use multiple imputation (MI) to handle missing data (Royston, 2004). We examined patterns of missing data using tabular and graphical representations and examined the appropriateness of imputations through diagnostic plots such as histograms and scatter plots, as well as trace plots of convergence (van Buuren, 2012). Although difficult to know with certainty, these observations and analyses of missing data patterns supported the assumption that data were missing at random (MAR) (Allison, 2002; van Buuren, Brand, Groothuis-Oudshoorn, \& Rubin, 2006; see also Manly \& Wells, 2015).

Given this assumption, we used MI, allowing us to retain a full analytic sample and diminish any biases that may have resulted had listwise deletion been used (Peugh \& Enders, 2004; Schafer \& Graham, 2002). Based on guidance by White, Royston, and Wood (2011) and Graham, 
Olchowski, and Gilreath (2007) about selecting an appropriate number of imputations, we created 35 imputations in both NELS and ELS using the mi impute chained command in Stata v.13. All variables, including the dependent variable, ${ }^{2}$ were included in the imputation models, which also included the primary sampling unit and strata based on the complex survey sampling design used by NCES, as well as the appropriate weights for each decade's dataset (Heeringa et al. 2010). We also decoded the NCES' single imputations in ELS for gender and race and then multiply imputed the missing data on those variables. We then used Rubin's (1987) pooling rules to combine the statistical results across the imputed datasets. ${ }^{3}$ Imputed and observed values were determined to be reasonably comparable, and results using both listwise deletion and MI are similar, so imputed results are presented.

\section{STATISTICAL ANALYSIS}

The analytic plan for this study consisted of three main parts: 1) descriptive statistics, including analyses of mean differences and change over time, 2) logistic regression to determine how SES predicts the use of college admission-enhancing strategies separately by cohort, including models testing interactions between SES and academic achievement, and 3) comparison of predicted probabilities of strategy use by SES within cohorts, as well as over time between cohorts.

For both NELS and ELS data, we calculated mean values of the admission-enhancing strategies for the full analytic sample and for each SES quartile. The resulting descriptive tables demonstrated how enhancement strategies were accessed and utilized differently across social classes (presented within each table), as well as how each changed over time (by comparing information between the tables). This was achieved by running simple regression models with SES quartile as the independent variable, with postestimation comparisons of the regression coefficients, which allowed us to account for the complex survey design of the data as well as weights. To examine change over time we calculated the difference between the means for ELS and NELS and displayed these changes in strategy usage in a separate table, using a $t$ test to indicate significant differences over time between the two cohorts.

Next, we employed logistic regression to investigate how SES predicted the use of the admission-enhancing strategies, while controlling for salient variables at the student and school levels. For each of the six dependent variables, we calculated odds ratios as effect sizes (Long, 1997). While there is no agreed-upon way to report goodness of fit statistics for logistic regression from data collected with a complex survey design and using MI, 
we opted to report the median value (from 35 imputed datasets) of multiple statistics. An F-adjusted mean residual test statistic is the only one that explicitly accounts for complex survey design via the suylogitgof command in Stata (Archer \& Lemeshow, 2006). We obtained the other statistics from weighted regressions assuming a simple design, which is a recommended alternative (Hosmer \& Lemeshow, 2000).

To address our second research question, we ran models for each dependent variable, with all independent variables as predictors, plus two additional interaction variables: one for SES interacting with math test score, and one for SES interacting with English test score. We examined the statistical significance of the interaction terms when included in the model separately, as well as when they were in the model simultaneously. We followed a conservative approach whereby we only retained interaction terms in those models when the results were statistically significant both individually and simultaneously.

Finally, to better understand how differences in SES relate to admissionenhancing strategy usage, we investigated predicted probabilities, which are more intuitive than regression coefficients or odds ratios. To do this, we calculated predicted probabilities of strategy use for the lowest and highest SES quartiles for each admission-enhancing strategy as well as overall high strategy use. We calculated probabilities based on the logistic regression results by setting all other independent variables to mean values. A comparison of predicted probabilities between the high- and low-SES groups is a more meaningful way to conceptualize inequality than the simple relationship between SES and the dependent variables, and is a recommended method to assess inequality in education (Lucas \& Byrne, 2011). Specifically, we calculated the associated group difference by subtracting the relevant probabilities, and calculated a $99 \%$ confidence interval around this difference (Long, 2009). ${ }^{4}$ A group difference was interpreted as statistically significant when the lowest bound of the confidence interval was greater than zero (confirmed by a significant p-value). Additionally, we compared the differences between high and low SES over time (i.e., comparing the SES difference in ELS to the SES difference in NELS) to determine if revealed inequality was maintained, diminished, or increased over time.

For models that had statistically significant interactions between SES and academic achievement variables, we calculated additional predicted probabilities across the range of achievement, for high- and low-SES students, with other variables set at the mean. These are displayed graphically to aid understanding of the ways that achievement and SES interact to predict strategy use. A confidence interval around the difference in predicted probabilities between high- and low-SES students is only displayed 
for differences that are significant. Additionally, to put this difference in context, the full variation in predicted probabilities across the ranges of both SES and academic achievement is shown in contour plots with the predicted probabilities indicated by shading and the high- and low-SES lines marked.

\section{LIMITATIONS}

As with most secondary data analyses, the variables that can be represented with the data are limited. Ideally there would be other admissionenhancing strategies included as dependent variables as well as additional control variables, which may subject our study to omitted variable bias. In addition, this study is focused on a traditional high school-to-college transition, and these strategies are unlikely to be as relevant for the increasing numbers of older students who enroll in college after a delay. They are also less relevant for admission to less-selective institutions. Finally, we examine change over time by comparing two sets of results, with a particular analytic strategy. While these are very good comparisons given that NELS and ELS are designed to be comparable, additional points in time, as well as alternate specifications of inequality, would be needed to confirm the trends in strategy use that we reveal over time.

\section{RESULTS}

\section{DESCRIPTIVE RESULTS}

Mean values for each enhancement strategy variable are shown in Table 1 (for NELS) and Table 2 (for ELS). (Mean values for all variables can be found in Table 9 in the appendix.) It is strikingly clear from the results that for each strategy, and for 'each cohort, the use of admission-enhancing strategies is nearly always greater among higher-SES students relative to lower-SES students. In other words, enhancement strategies are highly stratified by social class, and inequality in utilizing such strategies has persisted over the two decades analyzed in this study.

Tables 1 and 2 illuminate a number of gaps in the use of admission-enhancing strategies by SES, and we highlight a few of the largest from ELS (Table 2) as examples. While just over $30 \%$ of seniors took or were planning to take an AP exam in 2004, approximately $20 \%$ of low-SES students did so, compared to over $50 \%$ of high-SES students. Additionally, while the overall average for community service participation was quite high, with approximately $61 \%$ of students taking part in this strategy, over $80 \%$ of high-SES students performed community service compared to less than $50 \%$ of low-SES students. 
Table 1. Mean Values for Admission-Enhancing Strategies, by SES Quartile - NELS (1992)

\begin{tabular}{|c|c|c|c|c|c|c|}
\hline Strategy & All & $\begin{array}{c}\text { SES-1 }^{\text {st }} \\
\text { quartile } \\
\text { (1) }\end{array}$ & $\begin{array}{c}\text { SES-2 } \\
\text { quartile } \\
\text { (2) }\end{array}$ & $\begin{array}{c}\text { SES-3 }{ }^{\text {rd }} \\
\text { quartile } \\
(3)\end{array}$ & $\begin{array}{l}\text { SES-4 }{ }^{\text {th }} \\
\text { quartile } \\
(4)\end{array}$ & $\begin{array}{c}\text { Significant } \\
\text { differences } \\
(<.01)\end{array}$ \\
\hline $\begin{array}{l}\text { Took/planned AP } \\
\text { exam }\end{array}$ & $\begin{array}{c}0.168 \\
(0.006)\end{array}$ & $\begin{array}{c}0.079 \\
(0.007)\end{array}$ & $\begin{array}{c}0.114 \\
(0.008)\end{array}$ & $\begin{array}{l}0.158 \\
(0.009)\end{array}$ & $\begin{array}{c}0.347 \\
(0.015)\end{array}$ & All significant \\
\hline $\begin{array}{l}\text { Used any SAT } \\
\text { prep instruction }\end{array}$ & $\begin{array}{c}0.262 \\
(0.008)\end{array}$ & $\begin{array}{c}0.219 \\
(0.011)\end{array}$ & $\begin{array}{c}0.222 \\
(0.013)\end{array}$ & $\begin{array}{l}0.256 \\
(0.011)\end{array}$ & $\begin{array}{l}0.365 \\
(0.017)\end{array}$ & $4>3,4>2,4>1$ \\
\hline $\begin{array}{l}\text { Used any SAT } \\
\text { prep self-study }\end{array}$ & $\begin{array}{c}0.544 \\
(0.008)\end{array}$ & $\begin{array}{c}0.493 \\
(0.013)\end{array}$ & $\begin{array}{c}0.509 \\
(0.013)\end{array}$ & $\begin{array}{l}0.557 \\
(0.013)\end{array}$ & $\begin{array}{l}0.626 \\
(0.017)\end{array}$ & $\begin{array}{l}4>3,4>2,4>1, \\
3>2,3>1\end{array}$ \\
\hline $\begin{array}{l}\text { Extracurricular } \\
\text { leadership }\end{array}$ & $\begin{array}{c}0.382 \\
(0.007)\end{array}$ & $\begin{array}{c}0.278 \\
(0.011)\end{array}$ & $\begin{array}{c}0.364 \\
(0.013)\end{array}$ & $\begin{array}{l}0.398 \\
(0.012)\end{array}$ & $\begin{array}{l}0.504 \\
(0.015)\end{array}$ & $\begin{array}{l}4>3,4>2,4>1, \\
3>1,2>1\end{array}$ \\
\hline $\begin{array}{l}\text { Community } \\
\text { service }\end{array}$ & $\begin{array}{c}0.451 \\
(0.007)\end{array}$ & $\begin{array}{c}0.315 \\
(0.011)\end{array}$ & $\begin{array}{c}0.407 \\
(0.012)\end{array}$ & $\begin{array}{l}0.480 \\
(0.013)\end{array}$ & $\begin{array}{l}0.622 \\
(0.015)\end{array}$ & All significant \\
\hline $\begin{array}{l}\text { Overall high use } \\
\text { of strategies }\end{array}$ & $\begin{array}{l}0.117 \\
(0.006)\end{array}$ & $\begin{array}{l}0.042 \\
(0.004)\end{array}$ & $\begin{array}{c}0.082 \\
(0.009)\end{array}$ & $\begin{array}{l}0.113 \\
(0.008)\end{array}$ & $\begin{array}{l}0.252 \\
(0.015)\end{array}$ & All significant \\
\hline
\end{tabular}

While individual strategies are important, the measure of overall high strategy use is perhaps more important in terms of maximizing the desirability of an admissions profile. In 2004, about $19 \%$ of seniors participated in at least four of the five strategies examined in this study. When examining this measure of high usage across SES quartiles, approximately $10 \%$ of low-SES students were engaged in high strategy usage compared to over a third of high-SES students.

In examining Table 3, we found that students increased their use of all but one of the admission-enhancing strategies from 1992 to $2004 .{ }^{5}$ While these increases occurred across all SES groups, there are noticeably larger increases for the highest SES quartile. For example, while the proportion of students who participated in high levels of overall strategy use increased by about 7 percentage points on average between 1992 and 2002, highSES high strategy use increased by over 11 percentage points compared to a 4 - to 7-percentage-point increase for other SES groups. ${ }^{6}$ Overall, stratification by SES exists among high school seniors in both the utilization of admission-enhancing strategies and the magnitude of change over time. 
Table 2. Mean Values for Admission-Enhancing Strategies, by SES Quartile - ELS (2004)

\begin{tabular}{|c|c|c|c|c|c|c|}
\hline Strategy & All & $\begin{array}{c}\text { SES-1 }{ }^{\text {st }} \\
\text { quartile } \\
\text { (1) }\end{array}$ & $\begin{array}{l}\text { SES-2 } \\
\text { quartile } \\
\text { (2) }\end{array}$ & $\begin{array}{l}\text { SES-3 }{ }^{\text {rd }} \\
\text { quartile } \\
\text { (3) }\end{array}$ & $\begin{array}{l}\text { SES-4 }{ }^{\text {th }} \\
\text { quartile } \\
(4)\end{array}$ & $\begin{array}{c}\text { Significant } \\
\text { differences } \\
(<.01)\end{array}$ \\
\hline $\begin{array}{l}\text { Took/planned AP } \\
\text { exam }\end{array}$ & $\begin{array}{l}0.302 \\
(0.007)\end{array}$ & $\begin{array}{l}0.202 \\
(0.010)\end{array}$ & $\begin{array}{l}0.223 \\
(0.010)\end{array}$ & $\begin{array}{l}0.302 \\
(0.011)\end{array}$ & $\begin{array}{l}0.511 \\
(0.015)\end{array}$ & $\begin{array}{l}4>3,4>2,4>1, \\
3>2,3>1\end{array}$ \\
\hline $\begin{array}{l}\text { Used any SAT } \\
\text { prep instruction }\end{array}$ & $\begin{array}{l}0.299 \\
(0.007)\end{array}$ & $\begin{array}{l}0.247 \\
(0.012)\end{array}$ & $\begin{array}{c}0.249 \\
(0.012)\end{array}$ & $\begin{array}{l}0.297 \\
(0.012)\end{array}$ & $\begin{array}{l}0.420 \\
(0.015)\end{array}$ & $\begin{array}{l}4>3,4>2,4>1, \\
3>2,3>1\end{array}$ \\
\hline $\begin{array}{l}\text { Used any SAT } \\
\text { prep self-study }\end{array}$ & $\begin{array}{c}0.575 \\
(0.007)\end{array}$ & $\begin{array}{l}0.500 \\
(0.013)\end{array}$ & $\begin{array}{l}0.542 \\
(0.012)\end{array}$ & $\begin{array}{l}0.588 \\
(0.012)\end{array}$ & $\begin{array}{l}0.682 \\
(0.012)\end{array}$ & $\begin{array}{l}4>3,4>2,4>1, \\
3>2,3>1\end{array}$ \\
\hline $\begin{array}{l}\text { Extracurricular } \\
\text { leadership }\end{array}$ & $\begin{array}{l}0.334 \\
(0.006)\end{array}$ & $\begin{array}{l}0.221 \\
(0.010)\end{array}$ & $\begin{array}{l}0.293 \\
(0.011)\end{array}$ & $\begin{array}{l}0.361 \\
(0.010)\end{array}$ & $\begin{array}{l}0.480 \\
(0.013)\end{array}$ & All significant \\
\hline $\begin{array}{l}\text { Community } \\
\text { service }\end{array}$ & $\begin{array}{c}0.613 \\
(0.007)\end{array}$ & $\begin{array}{l}0.482 \\
(0.012)\end{array}$ & $\begin{array}{l}0.552 \\
(0.011)\end{array}$ & $\begin{array}{l}0.639 \\
(0.010)\end{array}$ & $\begin{array}{l}0.805 \\
(0.010)\end{array}$ & All significant \\
\hline $\begin{array}{l}\text { Overall high use } \\
\text { of strategies }\end{array}$ & $\begin{array}{l}0.186 \\
(0.006)\end{array}$ & $\begin{array}{l}0.096 \\
(0.007)\end{array}$ & $\begin{array}{l}0.123 \\
(0.008)\end{array}$ & $\begin{array}{l}0.186 \\
(0.009)\end{array}$ & $\begin{array}{l}0.365 \\
(0.013)\end{array}$ & All significant \\
\hline
\end{tabular}

Table 3. Change in Students' Use of Admission-Enhancing Strategies Between 1992 and 2004, by SES Quartile

\begin{tabular}{lccccc}
\multicolumn{1}{c}{ Strategy } & All & $\begin{array}{c}\text { SES-1 } \\
\text { quartile } \\
(1)\end{array}$ & $\begin{array}{c}\text { SES-2 } \\
\text { quartile } \\
(2)\end{array}$ & $\begin{array}{c}\text { SES-3 } \\
\text { quartile } \\
(3)\end{array}$ & $\begin{array}{c}\text { SES-4 } \\
\text { quartile } \\
(4)\end{array}$ \\
\hline Took/planned AP exam & $.134^{* *}$ & $.123^{* *}$ & $.109 * *$ & $.143^{* *}$ & $.164^{* *}$ \\
Used any SAT prep instruction & $.038^{* *}$ & $.028^{* *}$ & $.028^{* *}$ & $.041+$ & $.055+$ \\
Used any SAT prep self-study & $.031^{*}$ & $.007^{*}$ & $.033^{*}$ & $.031^{*}$ & $.056^{*}$ \\
Extracurricular leadership & & & & & \\
Community service & $-.048^{*}$ & $-.056^{*}$ & $-.07 *$ & $-.037 *$ & $-.024^{*}$ \\
Overall high use of strategies & & & & & $.183^{* *}$ \\
& $.163^{* *}$ & $.167^{* *}$ & $.145^{* *}$ & $.159^{* *}$ & $.113^{* *}$ \\
\hline
\end{tabular}

Note: ${ }^{* *} \mathrm{p}<.001 ;{ }^{*} \mathrm{p}<.01 ;+\mathrm{p}<.05$ 


\section{REGRESSION RESULTS}

We employed logistic regression to determine if SES was a significant predictor of admission-enhancement strategy usage in the 1990s and 2000s, net of demographic factors, academic background characteristics, and a host of other salient variables. Results in Table 4 (NELS) and Table 5 (ELS) confirm that even in the presence of these controls, SES was strongly related to most of the admission-enhancing dependent variables. Specifically, in 1992, increases in SES were associated with a higher likelihood of using all strategies except SAT self-study. In 2004, SES was a significant predictor of usage across all of the strategies. In examining AP exam participation, for example, a 1-standard-deviation increase in SES predicted an increase in the odds of AP exam participation by $38 \%$ and $34 \%$ for NELS and ELS, respectively. ${ }^{7}$ As another example, a 1-standard-deviation increase in SES predicted an increase in the odds of using at least four of the five strategies (high use) by 73-76\% for both cohorts.

Table 4. Predictors of Admission-Enhancing Strategies - Regression Analyses (NELS - 1992)

\begin{tabular}{|c|c|c|c|c|c|c|}
\hline Variable & $\begin{array}{c}\text { Took/ } \\
\text { plan AP } \\
\text { exam }\end{array}$ & $\begin{array}{c}\text { Any SAT } \\
\text { prep } \\
\text { instruction }\end{array}$ & $\begin{array}{c}\text { Any SAT } \\
\text { prep } \\
\text { self-study }\end{array}$ & $\begin{array}{l}\text { Extracurr. } \\
\text { leadership }\end{array}$ & $\begin{array}{l}\text { Community } \\
\text { service }\end{array}$ & $\begin{array}{c}\text { Overall } \\
\text { high strat- } \\
\text { egy use }\end{array}$ \\
\hline SES & $\begin{array}{l}1.380 * * \\
(0.079)\end{array}$ & $\begin{array}{l}1.364^{* *} \\
(0.073)\end{array}$ & $\begin{array}{c}1.112+ \\
(0.055)\end{array}$ & $\begin{array}{l}1.212^{* *} \\
(0.057)\end{array}$ & $\begin{array}{l}1.299 * * \\
(0.058)\end{array}$ & $\begin{array}{l}1.730 * * \\
(0.111)\end{array}$ \\
\hline $\begin{array}{l}\text { Math test } \\
\text { score }\end{array}$ & $\begin{array}{l}1.800 * * \\
(0.099)\end{array}$ & $\begin{array}{c}0.859 * \\
(0.044)\end{array}$ & $\begin{array}{c}0.976 \\
(0.041)\end{array}$ & $\begin{array}{l}1.228^{* *} \\
(0.052)\end{array}$ & $\begin{array}{l}1.291 * * \\
(0.055)\end{array}$ & $\begin{array}{l}1.349 * * \\
(0.081)\end{array}$ \\
\hline $\begin{array}{l}\text { Reading test } \\
\text { score }\end{array}$ & $\begin{array}{l}1.446^{* *} \\
(0.084)\end{array}$ & $\begin{array}{c}0.908 \\
(0.047)\end{array}$ & $\begin{array}{c}0.972 \\
(0.039)\end{array}$ & $\begin{array}{c}1.021 \\
(0.043)\end{array}$ & $\begin{array}{l}1.183^{* *} \\
(0.048)\end{array}$ & $\begin{array}{l}1.150+ \\
(0.068)\end{array}$ \\
\hline Female & $\begin{array}{c}1.096 \\
(0.084)\end{array}$ & $\begin{array}{c}1.134+ \\
(0.069)\end{array}$ & $\begin{array}{l}1.751^{* *} \\
(0.096)\end{array}$ & $\begin{array}{c}0.963 \\
(0.054)\end{array}$ & $\begin{array}{l}1.577 * * \\
(0.092)\end{array}$ & $\begin{array}{l}1.478^{* *} \\
(0.130)\end{array}$ \\
\hline Asian & $\begin{array}{l}1.916^{* *} \\
(0.249)\end{array}$ & $\begin{array}{l}1.646^{* *} \\
(0.201)\end{array}$ & $\begin{array}{l}1.723 * * \\
(0.219)\end{array}$ & $\begin{array}{c}0.809 \\
(0.095)\end{array}$ & $\begin{array}{c}0.949 \\
(0.104)\end{array}$ & $\begin{array}{c}1.627 * \\
(0.257)\end{array}$ \\
\hline Black & $\begin{array}{c}1.447+ \\
(0.262)\end{array}$ & $\begin{array}{l}2.346^{* *} \\
(0.290)\end{array}$ & $\begin{array}{l}1.872 * * \\
(0.220)\end{array}$ & $\begin{array}{c}1.090 \\
(0.131)\end{array}$ & $\begin{array}{c}1.036 \\
(0.116)\end{array}$ & $\begin{array}{l}2.344^{* *} \\
(0.544)\end{array}$ \\
\hline Latino & $\begin{array}{l}2.569 * * \\
(0.548)\end{array}$ & $\begin{array}{l}1.560^{* *} \\
(0.179)\end{array}$ & $\begin{array}{c}1.217+ \\
(0.121)\end{array}$ & $\begin{array}{c}0.897 \\
(0.095)\end{array}$ & $\begin{array}{c}1.208 \\
(0.119)\end{array}$ & $\begin{array}{c}1.456 \\
(0.289)\end{array}$ \\
\hline $\begin{array}{l}\text { Parental } \\
\text { expectations }\end{array}$ & $\begin{array}{c}1.569 * \\
(0.271)\end{array}$ & $\begin{array}{c}1.380 * \\
(0.144)\end{array}$ & $\begin{array}{l}1.645^{* *} \\
(0.136)\end{array}$ & $\begin{array}{c}1.242+ \\
(0.124)\end{array}$ & $\begin{array}{c}1.119 \\
(0.097)\end{array}$ & $\begin{array}{c}1.648+ \\
(0.386)\end{array}$ \\
\hline $\begin{array}{l}\text { College } \\
\text { expectations }\end{array}$ & $\begin{array}{l}1.677 * * \\
(0.198)\end{array}$ & $\begin{array}{l}1.475^{* *} \\
(0.122)\end{array}$ & $\begin{array}{l}1.321^{* *} \\
(0.089)\end{array}$ & $\begin{array}{l}1.531^{* *} \\
(0.121)\end{array}$ & $\begin{array}{l}1.323^{* *} \\
(0.091)\end{array}$ & $\begin{array}{l}2.282 * * \\
(0.339)\end{array}$ \\
\hline
\end{tabular}




\begin{tabular}{lcccccc}
\hline \multicolumn{1}{c}{ Variable } & $\begin{array}{c}\text { Took/ } \\
\text { plan AP } \\
\text { exam }\end{array}$ & $\begin{array}{c}\text { Any SAT } \\
\text { prep } \\
\text { instruction }\end{array}$ & $\begin{array}{c}\text { Any SAT } \\
\text { prep } \\
\text { self-study }\end{array}$ & $\begin{array}{c}\text { Extracurr. } \\
\text { leadership }\end{array}$ & $\begin{array}{c}\text { Community } \\
\text { service }\end{array}$ & $\begin{array}{c}\text { Overall } \\
\text { high strat- } \\
\text { egy use }\end{array}$ \\
\hline Peer college & $1.692^{* *}$ & $1.559^{* *}$ & $1.534^{* *}$ & $1.837 * *$ & $1.458^{* *}$ & $2.182^{* *}$ \\
plans & $(0.168)$ & $(0.116)$ & $(0.097)$ & $(0.122)$ & $(0.090)$ & $(0.260)$ \\
Constant & $0.025^{* *}$ & $0.168^{* *}$ & $0.367 * *$ & $0.170^{* *}$ & $0.362^{* *}$ & $0.014^{* *}$ \\
& $(0.005)$ & $(0.026)$ & $(0.052)$ & $(0.024)$ & $(0.047)$ & $(0.004)$ \\
Observations & 14,250 & 14,250 & 14,250 & 14,250 & 14,250 & 14,250 \\
-2 & $1,582,446$ & $2,436,732$ & $2,929,282$ & $2,814,250$ & $2,846,171$ & $1,350,010$ \\
log-likelihood & & & & & & \\
McFadden & 0.238 & 0.076 & 0.073 & 0.077 & 0.098 & 0.185 \\
Adj. R & & & & & & 0.502 \\
$\begin{array}{l}\text { F-adj. Mean } \\
\text { Residual }\end{array}$ & 3.619 & 1.482 & 0.667 & 0.659 & 1.785 & 0.574 \\
F-adj. p-value & $<0.001$ & 0.150 & 0.739 & 0.746 & 0.067 & 0.874 \\
\hline
\end{tabular}

Notes: Standard errors in parenthesis. ${ }^{* *} \mathrm{p}<.001 ;{ }^{*} \mathrm{p}<.01 ;+\mathrm{p}<.05$

All models also include controls for HS program, region, urbanicity, and \% high school free lunch.

All reported sample sizes are rounded to the nearest 10 in accordance with NCES restricted data license.

For a full model with all variables, see the online supplement at http://works. bepress.com/ryan_wells/22/.

Table 5. Predictors of Admission-Enhancing Strategies - Regression Analyses (ELS - 2004)

\begin{tabular}{lcccccc}
\hline Variable & $\begin{array}{c}\text { Took/ } \\
\text { planAP } \\
\text { exam }\end{array}$ & $\begin{array}{c}\text { Any SAT } \\
\text { prep } \\
\text { instruction }\end{array}$ & $\begin{array}{c}\text { Any SAT } \\
\text { prep } \\
\text { self-study }\end{array}$ & $\begin{array}{c}\text { Extracurr. } \\
\text { leadership }\end{array}$ & $\begin{array}{c}\text { Community } \\
\text { service }\end{array}$ & $\begin{array}{c}\text { Overall } \\
\text { high strat- } \\
\text { egy use }\end{array}$ \\
\hline SES & $1.335^{* *}$ & $1.590^{* *}$ & $1.256^{* *}$ & $1.312^{* *}$ & $1.461^{* *}$ & $1.757 * *$ \\
Math test & $(0.063)$ & $(0.086)$ & $(0.059)$ & $(0.057)$ & $(0.063)$ & $(0.100)$ \\
score & $1.704^{* *}$ & 0.980 & 1.060 & $1.290^{* *}$ & $1.185^{* *}$ & $1.386^{* *}$ \\
Reading test & $1.369^{* *}$ & $0.847^{* *}$ & 0.974 & $1.152^{* *}$ & $1.262^{* *}$ & $1.250^{* *}$ \\
Score & $(0.061)$ & $(0.039)$ & $(0.040)$ & $(0.047)$ & $(0.051)$ & $(0.065)$ \\
& $1.227 * *$ & $1.184^{*}$ & $1.989^{* *}$ & 0.989 & $1.854^{* *}$ & $1.681^{* *}$ \\
Female & $(0.068)$ & $(0.071)$ & $(0.116)$ & $(0.050)$ & $(0.095)$ & $(0.124)$ \\
& $1.794^{* *}$ & $1.906^{* *}$ & $1.824 * *$ & $0.814+$ & $1.255+$ & $1.861 * *$ \\
Asian & $(0.193)$ & $(0.216)$ & $(0.214)$ & $(0.084)$ & $(0.143)$ & $(0.213)$
\end{tabular}




\begin{tabular}{|c|c|c|c|c|c|c|}
\hline Variable & $\begin{array}{c}\text { Took/ } \\
\text { planAP } \\
\text { exam }\end{array}$ & $\begin{array}{c}\text { Any SAT } \\
\text { prep } \\
\text { instruction }\end{array}$ & $\begin{array}{c}\text { Any SAT } \\
\text { prep } \\
\text { self-study }\end{array}$ & $\begin{array}{l}\text { Extracurr. } \\
\text { leadership }\end{array}$ & $\begin{array}{c}\text { Community } \\
\text { service }\end{array}$ & $\begin{array}{c}\text { Overall } \\
\text { high strat- } \\
\text { egy use }\end{array}$ \\
\hline \multirow{2}{*}{ Black } & 0.916 & $1.927 * *$ & $2.180 * *$ & 1.101 & 1.101 & $1.433^{*}$ \\
\hline & $(0.100)$ & $(0.184)$ & $(0.216)$ & $(0.096)$ & $(0.096)$ & $(0.187)$ \\
\hline \multirow{2}{*}{ Latino } & $1.590 * *$ & $1.257+$ & 1.120 & $0.783^{*}$ & 0.994 & $1.338+$ \\
\hline & $(0.150)$ & $(0.119)$ & $(0.111)$ & $(0.068)$ & $(0.085)$ & $(0.160)$ \\
\hline \multirow{2}{*}{$\begin{array}{l}\text { Parental } \\
\text { expectations }\end{array}$} & $1.914^{* *}$ & $1.683 * *$ & $1.653 * *$ & $1.508^{* *}$ & $1.219+$ & $2.527 * *$ \\
\hline & $(0.206)$ & $(0.175)$ & $(0.149)$ & $(0.135)$ & $(0.096)$ & $(0.424)$ \\
\hline \multirow{2}{*}{$\begin{array}{l}\text { College } \\
\text { expectations }\end{array}$} & 1.031 & $1.369^{*}$ & $1.681^{* *}$ & $1.341^{*}$ & $1.464^{* *}$ & $1.744^{*}$ \\
\hline & $(0.124)$ & $(0.143)$ & $(0.161)$ & $(0.131)$ & $(0.124)$ & $(0.302)$ \\
\hline \multirow{2}{*}{ Constant } & $0.092 * *$ & $0.128 * *$ & $0.278^{* *}$ & $0.126 * *$ & $0.495^{* *}$ & $0.016 * *$ \\
\hline & $(0.015)$ & $(0.020)$ & $(0.041)$ & $(0.019)$ & $(0.062)$ & $(0.004)$ \\
\hline Observations & 12,440 & 12,440 & 12,440 & 12,440 & 12,440 & 12,440 \\
\hline $\begin{array}{l}-2 \\
\text { log-likelihood }\end{array}$ & $2,788,328$ & $3,135,275$ & $3,431,373$ & $3,209,602$ & $3,239,166$ & $2,205,983$ \\
\hline $\begin{array}{l}\text { McFadden } \\
\text { Adj. } R^{2}\end{array}$ & 0.180 & 0.073 & 0.093 & 0.091 & 0.125 & 0.174 \\
\hline $\begin{array}{l}\text { F-adj. Mean } \\
\text { Residual }\end{array}$ & 12.215 & 1.047 & 0.751 & 1.020 & 2.990 & 2.787 \\
\hline F-adj. p-value & $<0.001$ & 0.402 & 0.662 & 0.423 & 0.002 & 0.004 \\
\hline
\end{tabular}

Notes: Standard errors in parenthesis. ${ }^{* *} \mathrm{p}<.001 ;{ }^{*} \mathrm{p}<.01 ;+\mathrm{p}<.05$

All models also include controls for HS program, region, urbanicity, and $\%$ high school free lunch.

All reported sample sizes are rounded to the nearest 10 in accordance with NCES restricted data license.

For a full model with all variables, see the online supplement at http://works. bepress.com/ryan_wells/22/.

We also uncovered interesting results for independent variables other than SES. For instance, admission-enhancing strategies were utilized significantly more by females (versus males) and by nonwhite students (versus white students), controlling for other variables in the model. Additionally, we found statistically significant relationships across most of the dependent variables in relation to college expectations, peers' plans, and standardized test score. In other words, and perhaps not surprisingly, high achievers, who expect to go to college, and who are part of social networks where most students expect to go to college, are more likely to use admission-enhancing strategies. 
When we included variables in each of these regression models to represent the interaction between SES and math test score as well as SES and English test score, only one of these interaction terms was statistically significant across sensitivity analyses and across datasets, and for only one of the dependent variables. For AP exam participation, the interaction term for SES*Math test score was significant and positive (see Table 6 ). In other words, the positive relationship between SES and AP exam participation is even more positive when examined for higher-achieving students. However, this was the only outcome for which there appeared to be a variable gap in participation between low- and high-SES students based on academic achievement.

Table 6. Predictors of AP Exam Participation, Including Interaction Terms - Regression Analyses

\begin{tabular}{lcc}
\hline \multicolumn{1}{c}{ Variable } & NELS & ELS \\
\hline SES & 1.114 & $1.189^{* *}$ \\
Math test score & $(0.070)$ & $(0.060)$ \\
& $1.650^{* *}$ & $1.682^{* *}$ \\
English test score & $(0.099)$ & $(0.085)$ \\
& $1.389^{* *}$ & $1.327^{* *}$ \\
Math*SES & $(0.092)$ & $(0.061)$ \\
& $1.276^{* *}$ & $1.185^{*}$ \\
English*SES & $(0.093)$ & $(0.073)$ \\
& $1.196+$ & $1.366^{* *}$ \\
Constant & $(0.094)$ & $(0.082)$ \\
& $0.022^{* *}$ & $0.083^{* *}$ \\
Observations & $(0.005)$ & $(0.014)$ \\
-2 log-likelihood & 14,250 & 12,440 \\
McFadden Adj. $\mathrm{R}^{2}$ & $1,564,008$ & $2,749,828$ \\
F-adj. Mean Residual & 0.246 & 0.191 \\
F-adj. p-value & 1.659 & 6.172 \\
\hline Notes: Standard & 0.094 & $<0.001$ \\
\hline
\end{tabular}

Notes: Standard errors in parenthesis. ${ }^{* *} \mathrm{p}<.001 ;{ }^{*} \mathrm{p}<.01 ;+\mathrm{p}<.05$

All models also include controls for gender, race/ethnicity, parental expectations, student's expectations, peers' plans, HS program, region, urbanicity, and \% high school free lunch.

All reported sample sizes are rounded to the nearest 10 in accordance with NCES restricted data license.

For a full model with all variables, see the online supplement at http://works. bepress.com/ryan_wells/22/. 


\section{PREDICTED PROBABILITIES}

We used the regression results in Tables 4 and 5 to create predicted probabilities of strategy use for the highest- and lowest-SES groups specifically, holding all other values at their means. Table 7 (NELS) and Table 8 (ELS) show the predicted probabilities for each dichotomous outcome. We highlight two of our strategy variables as examples. First, in 1992 highSES students and low-SES students used SAT self-study strategies at relatively similar rates. The 4-percentage-point difference (57\% of high-SES students compared to $52 \%$ of low-SES students) was relatively small and not statistically significant. In 2004, $63 \%$ of high-SES seniors used SAT self-study strategies, an increase of about 7 percentage points from 1992. However, a fairly consistent $53 \%$ of low-SES students continued to use this strategy, resulting in a large and statistically significant gap by SES in the use of this strategy in 2004.

As another example, in 1992 (Table 6), students in the lowest SES quartile had a $3.8 \%$ probability of overall high strategy use compared to a $10.7 \%$ probability for a student from the highest SES quartile. This nearly 7-percentage-point difference is relatively large given the size of the probability, and was statistically significant. Similarly, when examining this same dependent variable in 2004 (Table 7), the estimated probabilities were $7.8 \%$ and $19.6 \%$ for low- and high-SES students, respectively; this difference of nearly 12 percentage points was large and statistically significant.

Table 7. Comparison of Predicted Probabilities of Admission-Enhancing Strategy Use for Low and High SES (NELS - 1992)

\begin{tabular}{lccccc}
\hline \multicolumn{1}{c}{ Strategy } & $\begin{array}{c}\text { SES-4 }^{\text {th }} \\
\text { quartile }^{\text {quar }}\end{array}$ & $\begin{array}{c}\text { SES-1 }^{\text {st }} \\
\text { quartile }\end{array}$ & Difference & $\begin{array}{c}\text { CI of } \\
\text { Difference }\end{array}$ & p value \\
\hline Took/planned AP exam & 0.126 & 0.070 & 0.056 & $(0.029,0.083)$ & 0.000 \\
SAT prep instruction & 0.302 & 0.188 & 0.114 & $(0.063,0.165)$ & 0.000 \\
SAT self-study & 0.574 & 0.521 & 0.053 & $(-0.011,0.117)$ & 0.032 \\
Extracurricular leadership & 0.415 & 0.325 & 0.090 & $(0.033,0.146)$ & 0.000 \\
Community service & 0.510 & 0.380 & 0.130 & $(0.073,0.185)$ & 0.000 \\
Overall high strategy use & 0.107 & 0.038 & 0.069 & $(0.045,0.093)$ & 0.000 \\
\hline
\end{tabular}


Table 8. Comparison of Predicted Probabilities of Admission-Enhancing Strategy Use for Low and High SES (ELS - 2004)

\begin{tabular}{|c|c|c|c|c|c|}
\hline Strategy & $\begin{array}{l}\text { SES-4 } \\
\text { quartile }\end{array}$ & $\begin{array}{l}\text { SES-1 } \\
\text { quartile }\end{array}$ & Difference & $\begin{array}{c}\text { CI of } \\
\text { difference }\end{array}$ & $p$ value \\
\hline Plans to/took AP exam & 0.304 & 0.203 & 0.101 & $\begin{array}{l}(0.058, \\
0.145)\end{array}$ & 0.000 \\
\hline SAT prep instruction & 0.377 & 0.202 & 0.175 & $\begin{array}{l}(0.123, \\
0.227)\end{array}$ & 0.000 \\
\hline SAT self-study & 0.634 & 0.530 & 0.104 & $\begin{array}{l}(0.049 \\
0.159)\end{array}$ & 0.000 \\
\hline $\begin{array}{l}\text { Extracurricular } \\
\text { leadership }\end{array}$ & 0.367 & 0.260 & 0.107 & $\begin{array}{l}(0.065, \\
0.154)\end{array}$ & 0.000 \\
\hline Community service & 0.712 & 0.548 & 0.164 & $\begin{array}{l}(0.116, \\
0.211)\end{array}$ & 0.000 \\
\hline $\begin{array}{l}\text { Overall high strategy } \\
\text { use }\end{array}$ & 0.196 & 0.078 & 0.118 & $\begin{array}{l}(0.086, \\
0.151)\end{array}$ & 0.000 \\
\hline
\end{tabular}

We next examined whether the differences in predicted probabilities between high- and low-SES groups changed over time. A comparison of Tables 7 and 8 reveals a few key findings. First, for all variables in each cohort, the estimated probabilities were higher for high-SES students than low-SES students. Second, with the exception of extracurricular leadership, the probabilities of strategy usage were higher for low- and high-SES groups in 2004 compared to 1992; in other words, on average, both highand low-SES students increased their use of these strategies over time.

Third, the differences in usage between high- and low-SES students were greater in 2004 than 1992, indicating that high-SES students were increasing their usage at a greater rate than low-SES students for most of the strategies, including their rate of overall high strategy use. While these increases in the SES gap are substantively important, one of the changes in differences between ELS and NELS was statistically significant at the.01 level-the increased SES gap in high strategy use. ${ }^{8}$ (The other changes over time were significant at the .05 level, with the exception of changes in the SES gap for community service, which was not statistically significant.) Finally, while all but one of these differences in predicted probabilities were significant in 1992, all six were statistically significant in 2004 . In total, these results reveal inequalities in the use of admission-enhancement strategies that were not only maintained over this time period, but which increased significantly.

Finally, we modeled predicted probabilities separately for AP exam participation, given the statistically significant interaction terms revealed in 
Table 6. Holding all other variables at their means, SES was again set at both the highest and lowest quartile values. In this case, however, math test score was also allowed to vary over the entire range of values. By graphing these probabilities, with high- and low-SES shown as separate lines in Figure 1, we visually show how the SES gap in AP participation varies for higher- and lower-achieving students, on average. For both NELS and ELS, the SES gap is only significant for the top half of the achievement distribution, and this gap grows as achievement values get larger. These same results are also represented in contour plots in Figure 2, over the full range of SES, with probability of participation shown by the degree of shading.

When comparing the NELS and ELS versions of these figures (i.e., differences in this phenomenon over time), there are two interesting trends. First, AP exam participation appears to be slightly more accessible to both lower-SES and lower-achieving students in the more recent ELS cohort. Second, the SES gap in AP participation for high achievers is smaller in the more recent cohort.

\section{DISCUSSION}

This study provides new empirical evidence for understanding inequality in the transition to higher education, for understanding how mechanisms of inequality have changed over time, for improving policy and practice related to college access, and as a basis for future research. Admissionenhancing strategies are valued in college admissions, and our results indicate three key findings related to them. First, SES is related to greater use of these strategies among high school students and this relationship has been maintained over time. This relationship remains true even after a host of salient variables are included as controls in the analytic models. Second, specifically comparing changes in the gap of strategy use between high- and low-SES students reveals that inequality has not only been maintained, but has increased over time. This is especially true of high strategy use, which is likely to be the most highly valued during admissions decisions. Third, the relationship between SES and AP participation varied over the range of students' academic achievement, which serves as a reminder that although SES has a clear stratifying effect, the fact that SES and achievement are also related can lead to more complicated and multilayered outcomes when considering college admissions. Our findings contribute to a growing body of literature examining educational inequalities, which as a whole will provide a better understanding of the myriad ways socially advantaged students exploit qualitative differences in educational experiences to maintain their social and educational advantages. 
Figure 1. Plot of the probability of AP exam participation, by math achievement, for high- and low-SES students, confidence interval shown only for significant differences

NELS

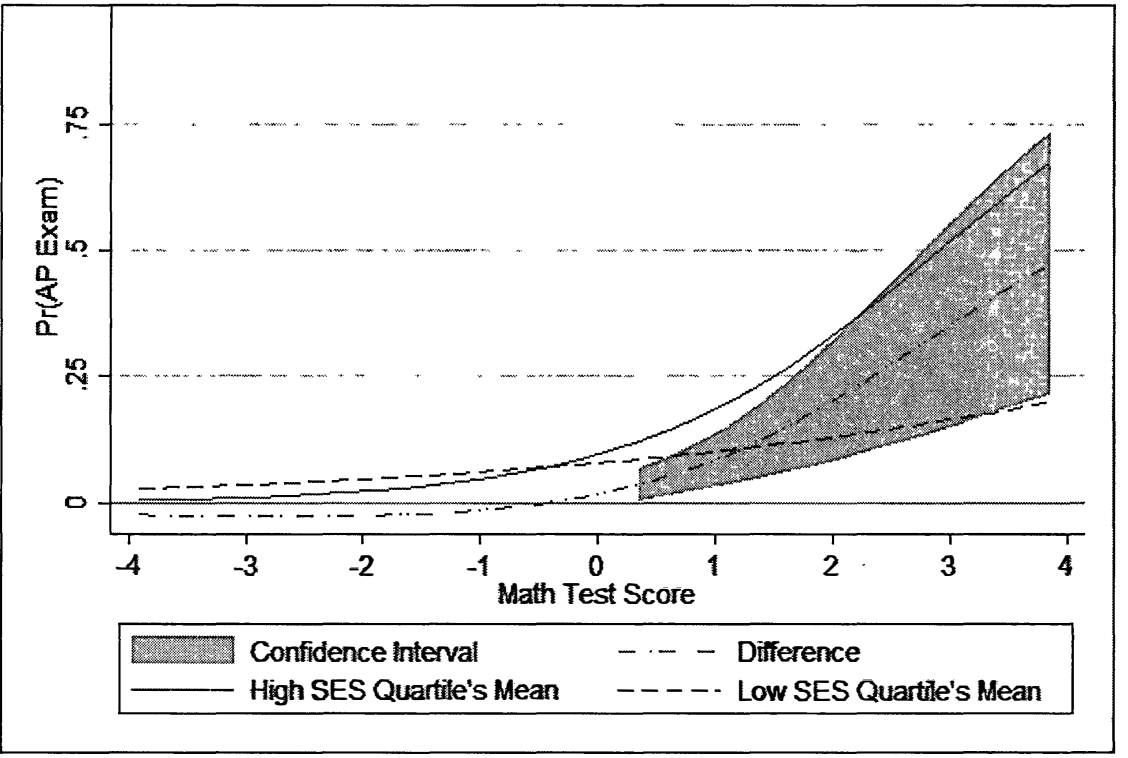

ELS

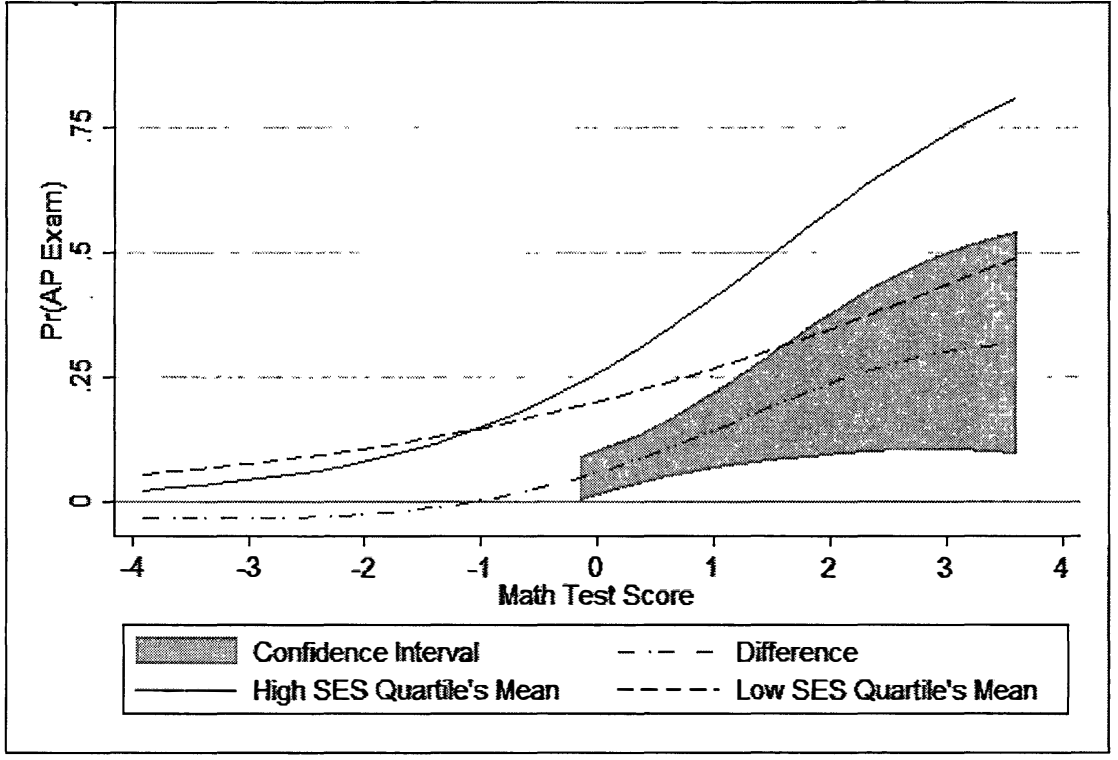


Figure 2. Contour plot representing the probability of AP exam participation, by SES and math achievement

NELS

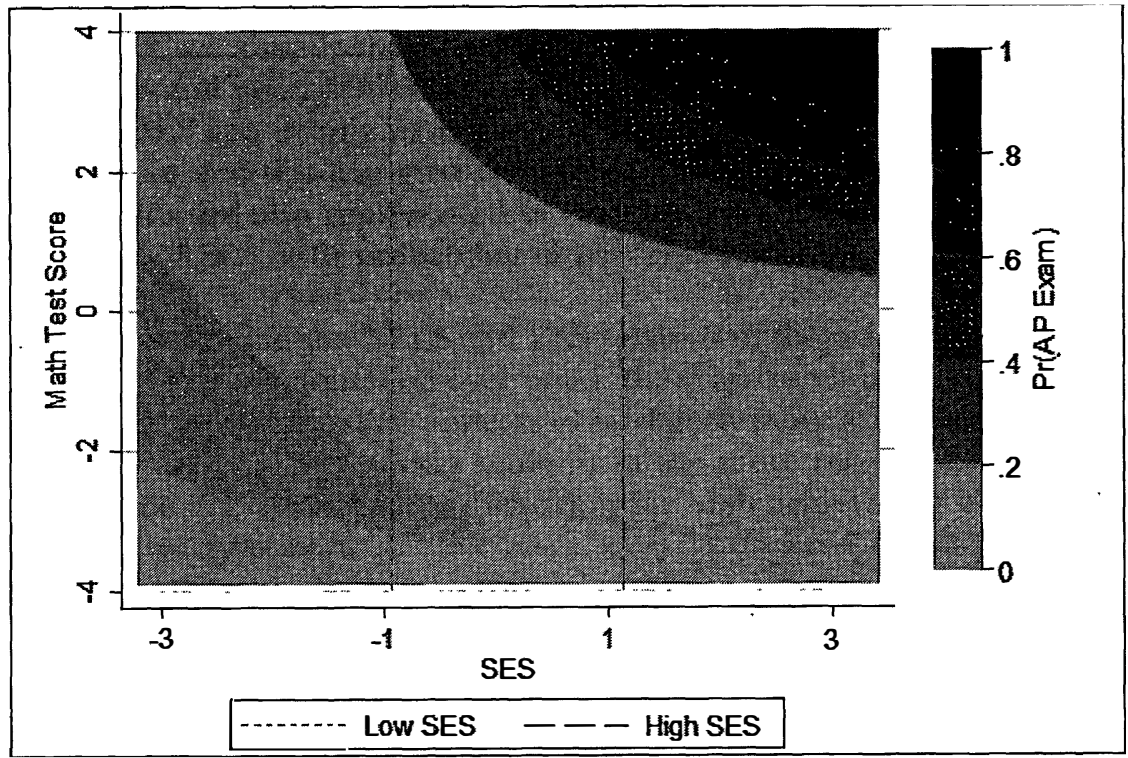

\section{ELS}

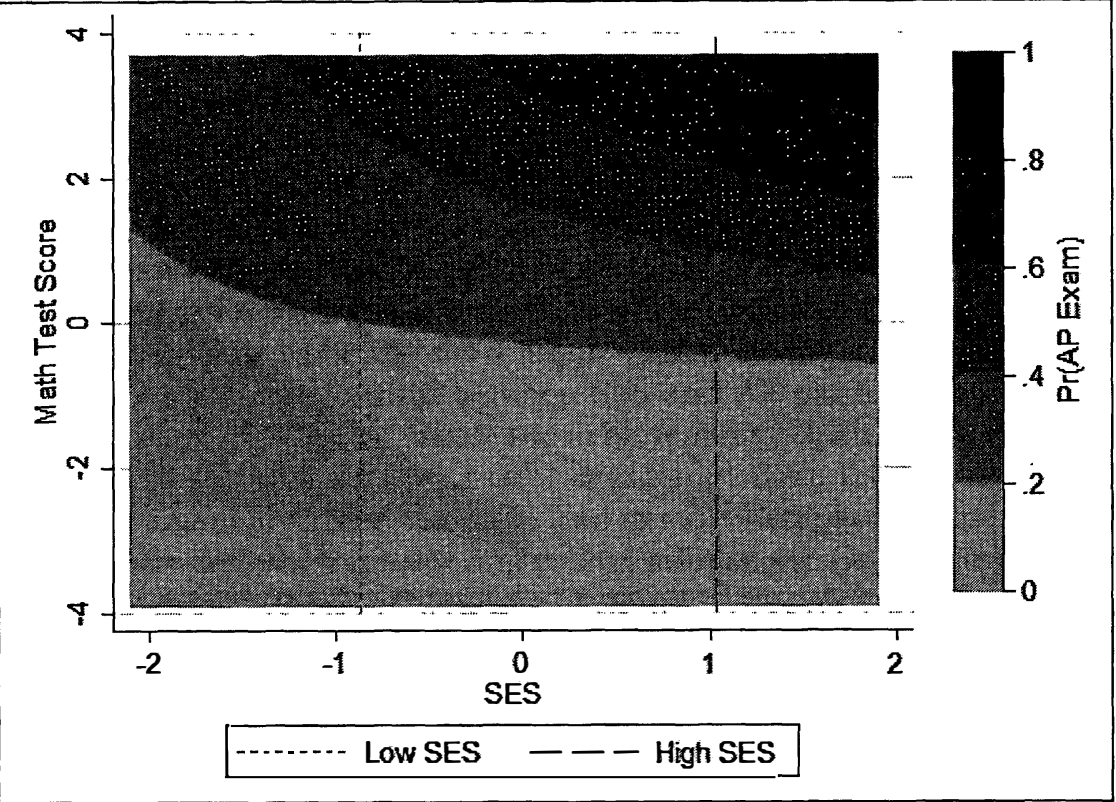




\section{SES AND ADMISSION-ENHANCING STRATEGIES}

One of the important findings of this study contributes to understanding the ways that SES is related to different admission-enhancing strategies over the last two decades. We found, for instance, that in most cases SES became a more prominent stratifying factor over time, with higher usage patterns as well as larger growth patterns uncovered for high-SES students compared to their low-SES counterparts. When coupled with the fact that high-SES students have outpaced their low-SES counterparts in terms of overall academic preparation (Bastedo \& Jaquette, 2011), it becomes clear that high-SES students have at least maintained, and often increased, their admissibility to selective institutions by taking full advantage of both academic and nonacademic opportunities valued by admission officers.

We found that high-SES students take greater advantage of AP exams and SAT preparation strategies compared to their low-SES counterparts, which improves their overall academic profile. Additionally, nonacademic strategies, such as participation in community service, are being used to a greater extent by high-SES students. Though usually less important than academic factors in college admission, foregoing the opportunity to participate in extracurricular leadership activities and community service may also attenuate a student's applicant profile at more selective institutions, even if these students are performing well academically. This is supported, in part, by recent data demonstrating the moderate importance placed on extracurriculars by many admission offices (Clinedinst et al., 2011), and by Espenshade and Radford's (2009) findings of a significant relationship between extracurricular involvement and admittance to an elite private college. High-achieving low-SES students may also simply not see selective institutions as realistic options (perhaps being poorly informed about the real costs of attending and opportunities to receive financial aid or not being counseled to consider these options) and thus may not see the need, or feel the pressure, to participate in activities that would enhance their college admissibility profiles.

Bowen, Kurzweil, \& Tobin (2005) found that low-income students were much less likely to get into the "credible applicant pool" (p. 100) for selective college admissions compared to their high-income peers, in part due to inadequate academic preparation. Hoxby and Avery (2012) more recently found that even when academically prepared, low-income students were much less likely to apply to selective institutions relative to their highincome peers with similar high achievement. Our findings suggest additional reasons that low-SES students are disadvantaged in the admission process, which may add to the disparities in college enrollment. 
This inequality can be interpreted through Alon's (2009) conceptualization of adaptations as well as Lucas' (2001) theory of EMI. Our results show that in most cases, students at all socioeconomic levels appear to have adapted to an increasingly competitive admissions environment in the 2000s by using enhancement strategies more often than in the 1990s. In this case, it does not appear that high-SES students used exclusion to maintain inequality. However, the extent to which adaptation occurred differentially by SES - evident from the greater changes in use over time for high-SES students-still effectively maintained, and even increased, inequality. This finding fits with Alon's conclusion that adaptations are more effective than exclusions for expanding inequality in higher education. For at least one strategy, however, the way that academic achievement influences these phenomena is important, and must not be neglected. When math achievement was allowed to moderate the relationship between SES and AP participation, the SES gap for higher-achievers appeared to narrow over time.

\section{IMPLICATIONS}

As academic achievement as well as enhancement strategies are judged to be meritorious and rewarded in college admissions (and especially selective admissions), this study reveals the pervasive role of SES in delimiting students' opportunities to access these strategies. Admissions processes and decisions should, therefore, be conducted with awareness of the stratifying nature of these admission-enhancing strategies and consider ways to account for differential utilization of these strategies by disadvantaged students. Many schools, for instance, that use comprehensive reviews are turning to noncognitive variables (Sedlacek, 2004), which speak to the importance of resiliency, coping, and support mechanisms in understanding student success in postsecondary education.

The findings and discussion lead to the suggestion that more programs are needed that foster greater involvement among low-SES students in activities, both academic and nonacademic, that will be seen as desirable by selective institutions and aid them in going to a college of their choice. Perhaps one obvious place to efficiently and effectively reach low-SES students is in schools that are predominantly low-SES. Incorporating admission-enhancing strategies in the organizational habitus of these schools would likely translate into a more robust college-going culture. The extent to which schools work to create an organizational habitus that highlights the benefits of extracurricular admission-enhancing strategies while simultaneously creating opportunities for test preparation and AP courses could work to offset some of the advantages benefitting higher-SES students in better-resourced schools. 
Given that we reveal more ways that low-SES students are disadvantaged in college access, the question arises as to whether low-SES students should be given a preference in college admission, a "thumb on the scale" ( $p$. 353) as Bowen et al. (2005) refer to it. This subject has been discussed and debated for some time, but it seems unlikely that American society would endorse class-based affirmative action given that the concepts of class are often denied or ignored in comparison to race. Additionally, it has been demonstrated that this approach would not create a racially diverse student body similar to those resulting under a policy of racial preference, and should not be used as a substitute, though perhaps in conjunction with racial preferences (Bowen et al., 2005; Espenshade \& Radford, 2009).

This study also reveals multiple avenues for future research. First, while beyond the scope of this study, our results reveal some intriguing results, including changes over time, in the way that race and gender predict enhancement strategy use. These preliminary results should be investigated more thoroughly to get a fuller picture of changing inequality, and not only inequality based on SES.

Future research should also investigate how enhancement strategies, along with SES, predict college enrollment and how those relationships may have changed over time. As demonstrated for AP exam use, the role of academic achievement must be considered and explicitly modeled when appropriate in such endeavors. Future analyses and studies related to this topic may also examine more closely how these enhancement strategies influence differing types of admission and enrollment while also investigating the cumulative effects that accrue from the use of more varied and/ or more refined types of admission-enhancing strategies. Researchers may also want to conduct a formal test of EMI theory in relation to admissionenhancing strategies. It may also be important to segment our findings by different school characteristics to better understand how schools structure opportunity and which ones seem to be most successful in more equitably distributing access to difference admission-enhancing strategies. 


\section{APPENDIX}

Table 9. Mean Values and Standard Errors of the Estimates, for All Analysis Variables

\begin{tabular}{|c|c|c|c|c|}
\hline \multirow[b]{2}{*}{ Variable } & \multicolumn{2}{|c|}{ NELS (1992) } & \multicolumn{2}{|c|}{ ELS (2004) } \\
\hline & Mean & Std. Error & Mean & Std. Error \\
\hline Took/planned AP exam & 0.168 & $(0.006)$ & 0.302 & $(0.007)$ \\
\hline Used any SAT prep instruction & 0.262 & $(0.008)$ & 0.299 & $(0.007)$ \\
\hline Used any SAT prep self-study & 0.544 & $(0.008)$ & 0.575 & $(0.007)$ \\
\hline Extracurricular leadership & 0.382 & $(0.007)$ & 0.334 & $(0.006)$ \\
\hline Community service & 0.451 & $(0.007)$ & 0.613 & $(0.007)$ \\
\hline Overall high use of strategies & 0.117 & $(0.006)$ & 0.186 & $(0.006)$ \\
\hline SES & 0.061 & $(0.017)$ & 0.054 & $(0.015)$ \\
\hline Math test score & 0.007 & $(0.019)$ & 0.011 & $(0.019)$ \\
\hline Reading test score & 0.015 & $(0.018)$ & 0.008 & $(0.018)$ \\
\hline Female & 0.506 & $(0.007)$ & 0.504 & $(0.006)$ \\
\hline \multicolumn{5}{|l|}{ Race/ethnicity: } \\
\hline Asian & 0.038 & $(0.003)$ & 0.047 & $(0.003)$ \\
\hline Black & 0.116 & $(0.008)$ & 0.140 & $(0.007)$ \\
\hline Latino & 0.091 & $(0.007)$ & 0.155 & $(0.008)$ \\
\hline Parental expectations & 0.806 & $(0.006)$ & 0.768 & $(0.006)$ \\
\hline Student's college expectations & 0.644 & $(0.007)$ & 0.828 & $(0.005)$ \\
\hline Peer college plans & 0.575 & $(0.007)$ & 0.538 & $(0.008)$ \\
\hline \multicolumn{5}{|l|}{ HS program: } \\
\hline College prep HS & 0.460 & $(0.008)$ & 0.539 & $(0.007)$ \\
\hline Vocational HS & 0.161 & $(0.005)$ & 0.098 & $(0.004)$ \\
\hline \multicolumn{5}{|l|}{ HS region: } \\
\hline Midwest HS & 0.271 & $(0.009)$ & 0.248 & $(0.007)$ \\
\hline Southern HS & 0.340 & $(0.009)$ & 0.341 & $(0.007)$ \\
\hline Western HS & 0.188 & $(0.007)$ & 0.223 & $(0.008)$ \\
\hline \multicolumn{5}{|l|}{ HS urbanicity: } \\
\hline Suburban HS & 0.417 & $(0.017)$ & 0.513 & $(0.009)$ \\
\hline Rural HS & 0.312 & $(0.016)$ & 0.203 & $(0.007)$ \\
\hline$\%$ HS on free lunch & 18.283 & $(0.615)$ & 22.212 & $(0.609)$ \\
\hline Observations & 14,250 & & 12,440 & \\
\hline
\end{tabular}

Notes: All reported sample sizes are rounded to the nearest 10 in accordance with NCES restricted data license.

Reference categories omitted: Race/ethnicity compared to white, HS program compared to a general program, HS region compared to northeast, HS urbanicity compared to urban. 


\section{NOTES}

1. For details about the specific operational definitions and NCES source variables used, as well as a correlation matrix, see our codebook in an online supplement here: http://works.bepress.com/ryan_wells/22/.

2. While some researchers have cautioned against using the dependent variable in an imputation model, Graham (2009) calls this a "myth" because not including the dependent variable "can be shown to produce biased estimates" (p. 559). Additionally, see patterns of missing data in our online supplement here: http:// works.bepress.com/ryan_wells/22/.

3 . We used Rubin's rules for pooling the predicted probability results specifically by using Stata's mi estimate command to pool results from a user-written program that ran logistic regression and subsequent margins commands to calculate predicted probabilities in a manner similar to the technique shown on UCLA's IDRE website: http://www.ats.ucla.edu/stat/stata/faq/ologit_mi_marginsplot.htm.

4. While it would be intuitive to simply include a confidence interval band around each predicted probability line and then simply see where they do not overlap to find areas of significant difference, this is not an appropriate way to examine group differences and would likely result in incorrectly showing fewer group differences than actually exist (Long, 1997, 2009; Shenker \& Gentleman, 2001).

5. While essentially the same information was gathered about extracurricular leadership, the data was gathered with a different series of survey items in ELS than in NELS, which could account for some difference on this particular item between cohorts.

6 . There are multiple ways to interpret change, which could lead to different conclusions. However, we adhere to a comparison of percentage-point changes over time to study SES gaps, similar to other scholars who used this approach to study inequality in college enrollment and completion (Bailey \& Dynarski, 2011).

7. Results of the F-adjusted mean residual test suggest that our models do not fit the data for AP exams or volunteering outcomes as well as they do for other outcomes. However, some researchers do not trust this test statistic (Allison, 2013) or acknowledge its limitations and conclude that it is perhaps more useful for comparing nested models (Agresti, 1990). The pseudo- $\mathrm{R}^{2}$ value, however, is a different type of model fit measure, indicating how well the independent variables predict the outcome. Results show reasonable values for this statistic, indicating that our models are still useful for answering our research questions concerning the extent to which SES predicts strategy use.

8. Statistical significance of the change in the differences over time was examined via a simple test statistic: $\left(d_{2}-d_{1}\right) / \sqrt{ }\left(s e_{2}{ }^{2}+s e_{1}{ }^{2}\right)$, where $d$ is the difference between high-and low-SES probabilities, $s e$ is the standard error of that difference, and the time periods (1 and 2) are NELS and ELS, respectively. 


\section{REFERENCES}

Adelman, C. (2002). The relationship between urbanicity and educational outcomes. In W.G. Tierney and L.S. Hagedorn (eds.), Increasing Access to College: Extending Possibilities for All Students (pp. 35-64). Albany, NY: State University of New York Press.

Adelman, C. (2006). The toolbox revisited: Paths to degree completion from high school through college. Washington, DC: U.S. Department of Education.

Agresti, A. (1990). Categorical data analysis. New York, NY: John Wiley \& Sons.

Allison, P. D. (2002). Missing data. Thousand Oaks, CA: Sage Publications.

Allison, P.D. (2013, March 5). Why I don't trust the Hosmer-Lemeshow test for logistic regression [Blog post]. Retrieved from http://www.statisticalhorizons.com/hosmer-lemeshow

Alon, S. (2009). The evolution of class inequality in higher education: Competition, exclusion, and adaptation. American Sociological Review, 74(5), 731-55.

lon, S., \& Tienda, M. (2007). Diversity, opportunity, and the shifting meritocracy in higher education. American SociologicalReview, 72(4), 487-511. doi:10.1177/000312240707200401

Archer, K. J., \& Lemeshow, S. (2006). Goodness-of-fit test for a logistic regression model fitted using survey sample data. Stata Journal, 6(1), 97-105.

Bailey, M. J., \& Dynarski, S. M. (2011, December). Gains and gaps: Changing inequality in U.S. college entry and completion (NBER Working Paper No. 17633). Cambridge, MA: National Bureau of Economic Research.

Bastedo, M. N., \& Jaquette, O. (2011). Running in place: Low-income students and the dynamics of higher education stratification. Educational Evaluation and Policy Analysis, 33(3), 318-339.

Bowen, W. G., Kurzweil, M. A., \& Tobin, E. M. (2005). Equity and excellence in American higher education. Charlottesville, VA: University of Virginia Press.

Briggs, D. C. (2002). SAT coaching, bias and causal inference (Unpublished doctoral Ph.D. dissertation). University of California, Berkeley.

Briggs, D. C. (2009). Preparation for college admission exams. Arlington, VA: National Association for College Admissions Counseling.

Buchmann, C., Condron, D. J., \& Roscigno, V. J. (2010). Shadow education, American style: Test preparation, the SAT and college enrollment. Social Forces, 89(2), 435-461.

Byun, S., \& Park, H. (2012). The academic success of East Asian American youth: The role of shadow education. Sociology of Education, 85(1), 40-60.

Clinedinst, M. E., Hurley, S. F., \& Hawkins, D. A. (2011). 2011 state of college admission. Alexandria, VA: National Association of College Admission Counseling. Retrieved from http://www.nacacnet.org/research/research-data/documents/2011soca.pdf

College Board. (2010). AP data 2010. New York, NY: Author. Retrieved from http://research. collegeboard.org/programs/ap/data/archived/2010

College Board. (2011). 7th annual AP report to the nation. New York, NY: Author.

College Board. (2012). Trends in College Pricing: 2012. NewYork, NY: Author. Retrieved from http:// trends.collegeboard.org/sites/default/files/college-pricing-2012-full-report-121203.pdf

Curtin, T. R., Ingels, S. J., Wu, S., Heuer, R., \& Owings, J. A. (2002). National Education Longitudinal Study of 1988: Base-year to fourth follow-up data file user's manual (NCES No. 2002-323). Washington, DC: Department of Education.

Dale, S. B., \& Krueger, A. B. (2014). Estimating the effects of college characteristics over the career using administrative earnings data. Journal of Human Resources, 49(2), 323-358. doi:10.1353/jhr.2014.0015

Deil-Amen, R., \& Tevis, L. (2010). Circumscribed agency: The relevance of standardized college entrance exams for low SES high school students. Review of Higher Education, 33(2), 141-175. 
Dote, L., Cramer, K, Dietz, N., \& Grimm, R. (2006). College students helping America. Washington, DC: Corporation for National and Community Service.

Duncan, O. D., Featherman, D. L., \& Duncan, B. (1972). Socioeconomic background and achievement. New York: Seminar Press.

Dye, T. R. (2002). Who's running America? The Bush restoration. London, England: Longman.

Engberg, M. E. (2012). Pervasive inequality in the stratification of four-year college destinations. Equity Ẽ Excellence in Education, 45(4), 575-595.

Engberg, M. E., \& Wolniak, G. C. (2010). Examining the effects of high school contexts on postsecondary enrollment. Research in Higher Education, 51(2), 132-153.

Espenshade, T. J., \& Radford, A. W. (2009). No longer separate, not yet equal: Race and class in elite college admission and campus life. Princeton, NJ: Princeton University Press.

Gibbs, B. G., Erickson, L. D., Dufur, M. J., \& Miles, A. (2015). Extracurricular associations and college enrollment. Social Science Research, 50, 367-381.

Graham, J. W. (2009). Missing data analysis: Making it work in the real world. Annual Review of Psychology, 60, 549-576. doi:10.1146/annurev.psych.58.110405.085530.

Graham, J. W., Olchowski, A. E., \& Gilreath, T. D. (2007). How many imputations are really needed? Some practical clarifications of multiple imputation theory. Prevention Science, 8, 206-213.

Grimm, R., Dietz, N., \& Foster-Bey, J. (2006). Volunteer growth in America. Washington, DC: Corporation for National and Community Service.

Grodsky, E., \& Jackson, E. (2009). Social stratification in higher education. Teachers College Record, 111, 2347-2384.

Haggerty, C., Dugoni, B., Reed, L., Cederlund, A., Taylor, J., \& Carroll, C. D. (1996). National educational longitudinal study: 1988-1994: Methodology report (NCES No. 96-174). Washington, DC: National Center for Education Statistics.

Hargrove, L., Godin, D., \& Dodd, B. (2008). College outcomes comparisons by AP and non-AP high school experiences. New York, NY: College Board.

Heeringa, S., West, B. T., \& Berglund, P. A. (2010). Applied survey data analysis. Boca Raton, FL: Chapman \& Hall.

Hosmer, D. W., \& Lemeshow, S. (2000). Applied logistic regression. New York, NY: Wiley.

Hossler, D., \& Stage, F. K. (1992). Family and high school experience influences on the postsecondary educational plans of ninth-grade students. American Educational Research Journal, 29, 425-451.

Hoxby, C. (2009). The changing selectivity of American colleges (NBER Working Paper No. 15446). Cambridge, MA: National Bureau of Economic Research. Retrieved from http://www. nber.org/papers/w15446.pdf?new_window=1

Hoxby, C., \& Avery, C. (2012). The missing "one-offs": The hidden supply of high-achieving, lowincome students (NBER Working Paper No. 18586). Cambridge, MA: National Bureau of Economic Research.

Ingels, S. J., Scott, L. A., Lindmark, J. T., Frankel, M. R., Myers, S. L., \& Wu, S. (1992). National educational longitudinal study of 1988: First follow-up: Student component data file user's manual (NCES No. 92-088). Washington, DC: National Center for Education Statistics.

Ingels, S. J., Pratt, D. J., Rogers, J., Siegel, P. H., \& Stutts, E. (2005). Educational longitudinal study of 2002: Base year to first follow-up data file documentation (NCES No. 2006-344). Washington, DC: National Center for Education Statistics.

Ingels, S. J., Pratt, D. J., Alexander, C. P., Jewell, D. M., Lauff, E., Mattox, T. L.,...Christopher, E. (2012). Educational longitudinal study of 2002: Third follow-up data file documentation (NCES No. 2014-364). Washington, DC: National Center for Education Statistics.

Kahne, J., \& Middaugh, E. (2008, February). Democracy for some: The civic opportunity gap in high school (CIRCLE Working Paper 59). College Park: University of Maryland, The Center for Information \& Research on Civic Learning \& Engagement. 
Karen, D. (2002). Changes in access to higher education in the United States: 1980-1992. Sociology of Education, 75(3), 191-210. doi:10.2307/3090265

Kaufman, J., \& Gabler, J. (2004). Cultural capital and the extracurricular activities of girls and boys in the college attainment process. Poetics 32(2), 145-68.

Klopfenstein, K. (2004). Advanced placement: Do minorities have equal opportunity? Economics of Education Review, 23(2), 115-131.

Klopfenstein, K., \& Thomas, M. K. (2009). The link between advanced placement experience and early college success. Southern Economic Journal, 75(3), 873-891.

Klugman, J. (2013). The Advanced Placement arms race and the reproduction of educational inequality. Teachers College Record, 115(5), 1-34.

Lacy, T. (2010). Examining AP: Access, rigor and revenue in the history of the advanced placement program. In P. M. Sadler, G.Sonnert, R. H. Tai, \& A. K. Klopfenstein (Eds.), $A P$ : A critical examination of the advanced placement program (pp. 17-48). Cambridge, MA: Harvard Education Press.

Long, J. S. (1997). Regression models for categorical and limited dependent variables. Thousand Oaks, CA: SAGE.

Long, J. S. (2009). Group comparisons in logit and probit using predicted probabilities. Bloomington, IN: Indiana University.

Lucas, S. R. (2001). Effectively maintained inequality: Education transitions, track mobility, and social background effects. American Journal of Sociology, 106, 1642-1690.

Lucas, S. R. (2009). Stratification theory, socioeconomic background, and educational attainment. Rationality and Society, 21(4), 459 -511. doi:10.1177/1043463109348987

Lucas, S., \& Byrne, D. (2011, August). Theory and method in the assessment of Effectively Maintained Inequality in comparative perspective. Paper presented at the International Sociological Association's Research Committee on Stratification and Social Mobility (RC28) Conference, Iowa City, IA.

Manly, C. A., \& Wells, R. S. (2015). Reporting the use of multiple imputation for missing data in higher education research. Research in Higher Education, 56(4), 397-409. http://doi. org/10.1007/s11162-014-9344-9

Marsh, H. W. (1992). Extracurricular activities: Beneficial extension of the traditional curriculum or subversion of academic goals? Journal of Educational Psychology, 84, 553-562.

Marsh, H. W., \& Kleitman, S. (2002). Extracurricular school activities: The good, the bad, and the nonlinear. Harvard Educational Review, 72(4), 464.

Marks, H. M., \& Jones, S. R. (2004). Community service in the transition: Shifts and continuities in participation from high school to college. Journal of Higher Education, 75(3), 307-339.

Morrow-Howell, N., Hong, S. I., \& Tang, F. (2009). Who benefits from volunteering? Variations in perceived benefits. The Gerontologist, 49(1), 91-102.

National Centerfor Education Statistics. (2012a). Digest ofEducation Statistics: 2012. Washington, DC: Author. Retrieved from http://nces.ed.gov/programs/digest/2012menu_tables.asp

National Center for Education Statistics. (2012b). Improving the measurement of socioeconomic status for the National Assessment of Educational Progress: A theoretical foundation. Washington, DC: Author.

Núñez, A.-M., \& Bowers, A. J. (2011). Exploring what leads high school students to enroll in Hispanic serving institutions: A multilevel analysis. American Educational Research Journal, 48(6), 1286-1313. doi:10.3102/0002831211408061

Orfield, G., \& Lee, C. (2006). Racial transformation and the changing nature of segregation. Cambridge, MA: The Civil Rights Project at Harvard University.

Paulsen, M. B., \& St. John, E. P. (2002). Social class and college costs: Examining the financial nexus between college choice and persistence. Journal of Higher Education, 73, 189-236. 
Peck, S. C., Roeser, R. W., Zarrett, N., \& Eccles, J. S. (2008). Exploring the roles of extracurricular activity quantity and quality in the educational resilience of vulnerable adolescents: Variable- and pattern centered approaches. Journal of Social Issues, 64(1), 135-56.

Perna, L. W. (2006). Studying college choice: A proposed conceptual model. In J. C. Smart (Ed.), Higher education: Handbook of theory and research (Vol. 21, pp. 99-157). New York, NY: Springer.

Perna, L. W., \& Titus, M. A. (2005). The relationship between parental involvement as social capital and college enrollment: An examination of racial/ethnic group differences. Journal of Higher Education 76(5), 485-518.

Peugh, J. L., \& Enders, C. K. (2004). Missing data in educational research: A review of reporting practices and suggestions for improvement. Review of Educational Research, 74(4), 525-556. doi:10.3102/00346543074004525

Royston, P. (2004). Mutliple imputation of missing values. Stata Journal, 4(3), 227-241.

Rubin, D. B. (1987). Multiple imputation for nonresponse in surveys. New York, NY: Wiley.

Schafer, J. L., \& Graham, J. W. (2002). Missing data: Our view of the state of the art. Psychological Methods, 7(2), 147-177. doi:10.1037/1082-989X.7.2.147

Schenker, N., \& Gentleman, J. F. (2001). On judging the significance of differences by examining the overlap between confidence intervals. The American Statistician, 55(3), 182-186.

Sedlacek, W. E. (2004). Beyond the big test: Noncognitive assessment in higher education. New York, NY: Wiley.

Soares, J. A. (2007). Power and privilege: Yale and America's elite colleges. Stanford, CA: Stanford University Press.

Spring, K. Dietz, N., \& Grimm, R. (2007). Leveling the path to participation: Volunteering and civic engagement among youth from disadvantaged circumstances. Washington, DC: Corporation for National and Community Service.

Stevens, M. L. (2007). Creating a class: College admission and the education of elites. Cambridge, MA: Harvard University Press.

Terenzini, P. T., Cabrera, A. F., \& Bernal, E. M. (2001). Swimming against the tide: The poor in American higher education (College Board Research Report). New York: The College Board.

Turley, R. N., Santos, M., \& Ceja, C. (2007). Social origin and college opportunity expectations across cohorts. Social Science Research, 36, 1200-1218.

van Buuren, S. (2012). Flexible imputation of missing data. Boca Raton, FL: CRC Press.

van Buuren, S., Brand, J. P. L., Groothuis-Oudshoorn, C. G. M., \& Rubin, D. B. (2006). Fully conditional specification in multivariate imputation. Journal of Statistical Computation and Simulation, 76(12), 1049-1064. doi:10.1080/10629360600810434

Weis, L., Cipollone, K., \& Jenkins, H. (2014). Class warfare: Class, race, and college admissions in top-tier secondary schools. Chicago, IL: University of Chicago Press.

Wells, R. S., \& Lynch, C. M. (2014). Volunteering for college? Potential implications of financial aid tax credits rewarding community service. Educational Policy, 28(6), 812-844.

White, I. R., Royston, P., \& Wood, A. M. (2011). Multiple imputation using chained equations: Issues and guidance for practice. Statistics in Medicine, 30, 377-399, doi:10.1002/sim.4067 